\title{
SoilUse and Management
}

\section{Effect of farm management on topsoil organic carbon and aggregate stability in water: case study from Southwest England, UK}

\begin{tabular}{|r|l|}
\hline Journal: & Soil Use and Management \\
\hline Manuscript ID & SUM-2020-252 \\
\hline Manuscript Type: & Research Paper \\
\hline Duthor: & 26-Jun-2020 \\
\hline Complete List of Authors: & $\begin{array}{l}\text { Collier, Sarah; University of Washington Seattle Campus, Department of } \\
\text { Environmental and Occupational Health Sciences } \\
\text { Green, Sophie; University of Exeter College of Life and Environmental } \\
\text { Sciences } \\
\text { Inman, Alex; University of Exeter, Land, Environment and Occupational } \\
\text { Health Sciences } \\
\text { Hopkins, David; SRUC Edinburgh Campus, } \\
\text { Kendall, Hazel; Westcountry Rivers Trust } \\
\text { Jahn, Molly; University of Wisconsin-Madison, Department of Agronomy } \\
\text { Dungait, Jennifer; University of Exeter College of Life and Environmental } \\
\text { Sciences; SRUC Edinburgh Campus, ; Rothamsted Research Sustainable } \\
\text { Soils and Grassland Systems Department, North Wyke }\end{array}$ \\
\hline Keywords: & $\begin{array}{l}\text { Agriculture, Soil management, Soil Organic Carbon (SOC), Soil Organic } \\
\text { Matter (SOM), Soil Policy, Tillage }\end{array}$ \\
\hline
\end{tabular}

\section{SCHOLARONE Manuscripts}


1 Effect of farm management on topsoil organic carbon and aggregate stability in water: 2 case study from Southwest England, UK

3

4 Authors: Sarah M. Collier ${ }^{1}$, Sophie M. Green², Alex Inman ${ }^{3}$, Tim Bearder $^{4}$, David W.

5 Hopkins $^{5}$, Hazel Kendall ${ }^{6}$, Molly M. Jahn ${ }^{7}$, Jennifer A. J. Dungait*2,4,5\#

6

7 Affiliations:

81 Department of Environmental and Occupational Health Sciences, University of

9 Washington, Seattle, Washington, USA

102 Geography, College of Life and Environmental Sciences, University of Exeter, Devon, UK

113 Land, Environment, Economics and Policy Institute, University of Exeter, Exeter, Devon,

12 UK

134 Department of Sustainable Soils and Grassland Systems, Rothamsted Research, North

14 Wyke, Devon, UK

155 SRUC - Scotland's Rural College, West Mains Road, Edinburgh, EH9 3JG, UK

166 Westcountry Rivers Trust, Stoke Climsland, Cornwall, UK

177 Department of Agronomy, University of Wisconsin-Madison, Madison, Wisconsin, USA

18

19 \# Current address

$20 *$ Corresponding author: Jennifer Dungait, Email: j.dungait@exeter.ac.uk 


\section{Abstract}

23

There are few reliable datasets to inspire confidence in policymakers that soil organic carbon (SOC) can be measured on farms. We worked with farmers in the Tamar Valley region of southwest England to select sampling sites under similar conditions (soil type, aspect and slope) and management types. Topsoils $(2-15 \mathrm{~cm})$ were sampled in autumn 2015 and percentage soil organic matter (\%SOM) was determined by loss-on-ignition and used to calculate \%SOC. We also used the stability of macroaggregates in cold water (WSA) ('soil slaking') as a measure of 'soil health' and investigated its relationship with SOC in the clayrich soils. \%SOM was significantly different between management types in the order woodland $(11.1 \%)=$ permanent pasture $(9.5 \%)>$ ley-arable $(7.7 \%)=$ arable $(7.3 \%)$. This related directly to SOC stocks that were larger in fields under permanent pasture and woodland compared to those under arable or ley-arable rotation whether corrected for clay content $(F=8.500, p<0.0001)$ or not $(F=8.516, p<0.0001)$. WSA scores were strongly correlated with SOC content whether corrected for clay content $\left(\mathrm{SOC}_{\text {adj }} R^{2}=0.571, p<\right.$ $0.0001)$ or not $\left(\mathrm{SOC}_{\text {unadj }} R^{2}=0.490, p=0.002\right)$. Time since tillage controlled SOC stocks and WSA scores accounting for $75.5 \%$ and $51.3 \%$ of total variation, respectively. We conclude that (1) SOC can be reliably measured in farmed soils using accepted protocols and related to land management and (2) WSA scores can be rapidly measured in clay soils and related to SOC stocks and soil management.

Keywords Carbon sequestration; aggregate stability; soil health; agriculture; management type; tillage

\section{Highlights}


46 - On-farm SOC measurements are rare and prevent the development of a reward system

47

48

49

50

51

52

53 for farmers

- SOC was measured in samples of clay-rich soil from different management types on 14 farms in the same region

- Stability of aggregates in water was directly related to SOC stocks

- Time since tillage controlled SOC and WSA that can both be reliably measured on farm soils using widely available technologies 


\section{Introduction}

Rural businesses have a positive role to play in climate change mitigation because there is significant potential for carbon dioxide $\left(\mathrm{CO}_{2}\right)$ to be removed from the atmosphere by the process of photosynthesis and stored as living biomass (vegetation) or as soil organic carbon (SOC; i.e. carbon sequestration) in agricultural soils (Lal, 2018). In general, agricultural soils are degraded relative to their pre-agricultural condition and therefore have a capacity for SOC stocks to be rebuilt if managed appropriately (Sanderman et al., 2017). The target of 0.4 tonnes carbon (i.e. $0.4 \%$ ) per hectare per year in the top $40 \mathrm{~cm}$ of soil was described as achievable in the ' 4 per mille' initiative launched by the French Government at the Paris Climate Summit (COP21) (Soussana et al., 2019), although the scientific basis for this is debated (Poulton et al., 2018). Nevertheless, for a range of environmental and agricultural reasons, there are few if any circumstances where an increase in SOC would not be beneficial. SOC is a key indicator of soil health (Lal, 2016) because it promotes the agents and mechanisms of aggregation important for maintaining soil physical condition (Jensen et al., 2019), thereby aiding the infiltration of air, water and nutrients, and promoting water and nutrient retention and sequestering carbon (Stockmann et al., 2013). Consequently, optimising carbon storage in agricultural soils is regarded as a win-win strategy providing multiple benefits, foremost the sustainable production of crops through increased soil fertility and improved soil structure (Paustian et al., 2019).

The protection of peatland and other organic soil carbon stocks, and the management of cropland, grassland and forest soils to increase carbon sequestration, will be crucial to the maintenance of the UK carbon balance (Ostle et al., 2009). Yet, this potential remains frustrated by the apparent difficulty in establishing how to monitor changes in SOC in agricultural land efficiently and effectively with sufficient confidence beyond research 
settings (de Gruijter et al., 2016). A plethora of formal scientific studies have explored the impacts of various crop and soil management practices on SOC/soil organic matter (SOM) and resultant crop responses (e.g. Meng et al., 2018), some that have been running for almost two hundred years (Christensen and Johnston, 1997). It is fair to say that we understand the basic controls on SOC and know reasonably well which management practices can be used to increase SOC storage across a wide range of environments (Paustian et al., 2019), including regions of the UK (King et al., 2004; Thomas et al., 2020). Indeed, the successful measurement of SOC in land across England and Wales and Scotland has been carried out using standardised methodologies as part of the Countryside Survey in 1978, 1998 and 2007 (Reynolds et al., 2013; Thomas et al., 2020) amongst other initiatives (e.g. Howard et al. 1995; Chapman et al. 2013).

The search for reliable soil health indicators is in a state of limbo in the UK as the debate over the most appropriate metric is confounded by lack of local evidence. Yet, a suite of soil health indicators is used by farmers for the reliable and comparable assessment of their soils in the USA based on methods developed for the assessment of physical soil quality more than 30 years ago, e.g. Doran \& Parkin (1997), and supported by the resources of the USDAARS/NRCS. Of these, soil aggregate stability in water (or 'the slake test') is widely recognized as a key indicator of soil quality and health, and methods for in-field assessment developed by Herrick et al. (2001) are regularly used in the USA for rapid evaluation by farmers and advisors, but infrequently in the UK. Stable macroaggregates (1-10 mm size range) are soil components observed by eye during the examination of soil structural quality using the spade method that indicates the quality of soil structure in agricultural soils, i.e. Visual Examination of Soil Structure (VESS; Ball et al., 2007). The progressive reduction of SOC in cropland soils (Heikkinen et al., 2013) and mechanical destruction of soil structure by 
reduce the number and stability of macroaggregates. The biological contributions to aggregate stability are dependent on the supply and turnover of SOC by microorganisms (Tisdall and Oades, 2006); therefore, stable aggregates may serve as a proxy for SOC for efficient field assessments. However, the clay content of soils with expanding clay mineralogy may confound the influence of SOC content on aggregate stability because soils with more than $15-20 \%$ clay usually demonstrate moderate-to-strong aggregate structure (Jarvis, 2007). Thus, the relationship between soil slaking and SOC content may be reduced in soils with large clay contents, making the test an unreliable proxy in the slowly permeable, clay-rich 'heavy' soils that are typical in many areas of England under agricultural management type. \%SOM by loss-on-ignition and the stability of soil macroaggregates in water) to discern the effects of different management practices on SOC stocks in working farmland soils, thereby encompassing all of the idiosyncrasies typical of real rural businesses that are absent in the unavoidably artificial scenarios of scientific experiments. We focussed on topsoils because the effect of soil management and field operations is most notable here (Thomas et al., 2020) (although we well recognise that management of surface soils has significant effects on SOC dynamics in deeper soil horizons, e.g. Collier et al., 2017, Gregory et al., 2016). We tested the overarching hypothesis that variations in SOC stocks in agricultural soils can be measured and related to land management. The hypothesis was tested by meeting two objectives: (1) to test the ability of standard methods to discern a correlation between SOC stocks and historical management practices on working farmland; and (2) to establish whether a 
commonly used indicator of soil quality, the stability of soil (macro)aggregates in water ('the slake test'), can be used as a proxy measurement for SOC.

\section{Materials and methods}

\subsection{Site characteristics and management history}

This study was carried out in 2015 and was focused on farmland within the Tamar Valley

Catchment in Devon and Cornwall, southwest England. Soil survey maps (Soil Survey of England and Wales, 1997, Sheets SS 30 and SX47; scale 1:25,000; Harrod, 1997; 1998) were used to identify areas with similar soil types that were typical of the region: slightly acidic loamy and clayey soils with impeded drainage (Endoleptic Stagnic Cambisols or Clayic Eutric Stagnosols; WRB, 2006). Fourteen farms were selected based on soil type, management types and the opportunity to access. Twelve were in the Tamar Catchment in Devon and Cornwall, one was near Truro in Cornwall and two plots were at Rothamsted Research North Wyke near Okehampton, Devon (Rowden Moor, 5046'13"N, 353'55"W, $50^{\circ} 46^{\prime} 14^{\prime \prime} \mathrm{N}, 3^{\circ} 53^{\prime} 51^{\prime \prime} \mathrm{W}$; North Wyke Farm, 5046'29"N, 3⒌'38"W, 5046'28"N, $\left.3^{\circ} 55^{\prime} 49^{\prime \prime} \mathrm{W}\right)$ (Figure S1). The coordinates of the commercial farms are withheld to maintain anonymity. Fields under different management were selected in collaboration with each farmer. In addition to detailed management history for the past five years, farmers were asked to provide general management type history from the present up to a maximum of 100 years ago where possible, which allowed the calculation or estimation of time since last tillage (TST) for each field. The number of fields sampled on each farm ranged from two to seven, and 40 fields were sampled in total.

\subsection{Soil sampling}


Site visits and soil sampling were conducted between 8 October and 23 November 2015. One

154

155

156

157

\section{4}

75

sampling site $\left(1 \mathrm{~m}^{2}\right)$ was selected per field based on predetermined topographic criteria (soil type and shallow slope angle or midslope) and guidance from farmers about in-field soil characteristics and representativeness. The method for the quantification of SOC concentration in soils used loss-on-ignition (LOI), and then the calculation of SOC stocks ( $\mathrm{t}$ $\mathrm{C} \mathrm{ha}^{-1}$ ) using the bulk density of the same soil. At each sampling site, a screw auger (up to 60 cm depth) was used to measure topsoil depth and confirm soil type. Three soil cores were taken with a root auger ( $8 \mathrm{~cm}$ diameter, $15 \mathrm{~cm}$ depth; Van Walt Root Auger, Surrey, UK) in a triangle at $50 \mathrm{~cm}$ radius around the central screw auger hole. After sampling, the top $2 \mathrm{~cm}$ of each core was removed to aid comparison between soils under different vegetation types, providing an effective sampling depth of $2-15 \mathrm{~cm}$. The cores were processed and analysed individually. Additional samples ( $\sim 500 \mathrm{~g})$ were collected along the edge of each root auger hole $(2-15 \mathrm{~cm})$ using a trowel for use in the assessment of aggregate stability. All samples were stored at $4{ }^{\circ} \mathrm{C}$ until analysis.

\subsection{Soil analysis}

In the laboratory, each soil core was crumbled and dried at $105^{\circ} \mathrm{C}$ to constant weight in a fan-assisted oven, and the dry weight recorded. The samples were ground to pass a $2 \mathrm{~mm}$ sieve, and the weight and volume of debris (i.e. plant leaf and root litter and stones) remaining on the sieve $(>2 \mathrm{~mm})$ were recorded. Bulk density $\left(\mathrm{BD}, \mathrm{g} \mathrm{cm}^{3}\right)$ for each core $(n=$ 3 per field) was calculated as:

$$
B D=\frac{(\text { dry weight of sample }- \text { dry weight of debris })}{(\text { volume of soil core }- \text { volume of debris })} \quad \text { Equation } 1
$$


Soil $\mathrm{pH}$ was determined in a 1:1 deionised water:soil suspension using an electronic $\mathrm{pH}$ probe calibrated with standard $\mathrm{pH} 4$ and 7 buffer solutions. Total carbon (TC) and nitrogen (TN) contents were determined on finely ground subsamples by combustion using a Carlo Erba NA2000 analyser (CE Instruments, Wigan, UK). Particle size distribution (\% sand:silt:clay) was determined using the Bouyoucos hydrometer method (Gee and Baulder, 1986).

Soil organic matter (SOM) content (\% dry matter) of three replicate $30 \mathrm{~g}$ subsamples each

from each core soil was determined using loss-on-ignition (LOI) by heating at $400{ }^{\circ} \mathrm{C}$ for $16 \mathrm{~h}$ (Davies, 1974; Schulte et al., 1991). \%SOM was calculated as the difference between the initial dry soil weight and the ashed soil weight. The influence of clay on \%SOM was determined using the calculation used by the Soil Survey of England and Wales published in Harrod \& Hogan (2008) to allow direct comparison with previous data pertinent to the study

or adjusted for clay content

$$
\text { SOC stock }=\left(\frac{\% S O M)}{1.72}\right) \times B D \times \operatorname{depth} \times 100
$$

Equation 2 area. Thus, SOC stocks $\left(\mathrm{t} \mathrm{C} \mathrm{ha}^{-1}\right)$ for the sampling depth were calculated without adjustment for clay content

$$
\text { SOC stock }=\left(\frac{\% \text { SOM }-(\% \text { clay } \times 0.1)}{1.72}\right) \times B D \times \text { depth } \times 100
$$

Equation 3 were arranged on a $2 \mathrm{~mm}$ sieve and gently immersed in deionized water. The aggregates were observed for five minutes, then the sieve was raised up and down five times, with 
approximately 1 second transit time up and 1 second down, allowing surface tension at the zenith to slightly disrupt the aggregates. A score of $0-8$ was determined by observing the behaviour of the aggregates in water using the criteria described in Table 1.

\subsection{Statistical analysis}

All statistical analysis was completed using XLSTAT 20193.1 for Microsoft Excel 2016 (Addinsoft, New York, USA). One-way ANOVA was used to assess the significant differences between management types in relation to SOC, TN, WSA, BD, topsoil depth and sand and clay content. ANOVA assumptions were verified and the data transformed (BoxCox) where necessary to satisfy the normality criterion. Where $p \leq 0.05$, Tukey's HSD (honest significant difference) test was used to identify which management types were significantly different from each other. TST and WSA failed the normality criterion even after transformation, so a Kruskal-Wallis test was applied and the means comparison was evaluated using Dunn's (1964) test.

Non-linear curve estimation and Akaike Information Criterion (AIC) was used to determine the best model relationship between SOC stocks (unadjusted and adjusted for clay) and TST. Multiple linear regression (Best Model) was used to determine the significantly contributing variables (entry: $p \leq 0.05$, removal: $p \leq 0.1$ ) and corrected Akaike Information Criterion (AICc) to compare models for SOC (stock, unadjusted and adjusted for clay) and WSA. Variables were considered as three groups: management variables $\left(\log _{10}(\mathrm{TST})\right)$, dependent soil variables (SOC, TN and WSA) and independent soil variables (topsoil depth, and \% sand and clay). SOC was analysed as stocks except when considered as a predictor of WSA, while $\mathrm{TN}$ was analysed as concentration only. All variables were first analysed for correlation with SOC and with WSA using a correlation matrix to determine their suitability for inclusion 
227 (Table S1). Topsoil depth, \%clay and \%sand were excluded at this stage from further analysis. Per ANOVA, the assumptions for multiple linear regression were validated. Wilcoxon matched-pairs test was used to assess the SOC clay correction differences.

\section{Results}

\subsection{Soil properties by management type}

All of the fields included in the study had been under their current management system for at least eight years. Of the 40 fields sampled, four were under arable management and were ploughed every year; 11 were in ley-arable rotation, having been ploughed at least once in the past three years; 20 were in permanent pasture, having last been tilled from between three and 75 years ago; and five were woodlands last known or estimated to have been tilled from 15 to over 100 years ago (Tables 2). Topsoil depth ranged from 17 to $59 \mathrm{~cm}$ (mean 33, median 32), with no significant differences between management types (Table 2: $F=2.215, p=0.103$ ). Soils had mean sand and clay contents of $46 \%$ (range 28 to $60 \%$ ) and $23 \%$ (range 10 to $36 \%$ ), respectively (Table S2) and represented loam, clay loam and sandy clay loam textural classes. Mean bulk densities were not significantly different between management types (Table 2: $F=$ $2.324, p=0.091)$. Soil $\mathrm{pH}$ values were moderately to strongly acidic and were significantly different between management types in the order: ley-arable $(6.1)=$ arable $(5.8)>$ permanent pasture $(5.2)=$ woodland $(4.6)($ Table $2: F=14.68 ; p<0.0001) . \% \mathrm{TN}$ was significantly different between land uses in the order: permanent pasture $(0.5 \%)=$ woodland $(0.5 \%)>$ leyarable $(0.4 \%)>$ arable $(0.4 \%)($ Table $2: F=4.097 ; p=0.013) . \%$ SOM was significantly different between land uses in the order woodland $(11.1 \%)=$ permanent pasture $(9.5 \%)>$ leyarable $(7.7 \%)=$ arable $(7.3 \%)($ Figure 1a; Table $2: F=7.016 ; p=0.001)$ 
252 Correcting for clay content made a significant difference to the calculation of $\%$ SOC from

253

254

255

256

257

258

259

260

261

262

263

264

265

266

267

268

269

270

271

272

273

274

275

$\%$ SOM estimates for all management types (Figure 1a; $p<0.0001$; Figure 1a), with claycorrected SOC concentration values $\left(\mathrm{SOC}_{\mathrm{adj}}\right.$ ) on average $28 \%$ lower than those without clay correction $\left(\mathrm{SOC}_{\mathrm{unadj}}\right)$. Mean $\mathrm{SOC}_{\mathrm{adj}}$ concentrations were similar to those determined using elemental analysis (\%TC) for all management types: $2.9 \%$ for arable, $3.2 \%$ for ley-arable, $4.0 \%$ for permanent pasture and $4.4 \%$ for woodland (Figure 1a). Regardless of correction for clay content, significant differences in $\% \mathrm{SOC}$ were observed (Table 2 : $\mathrm{SOC}_{\text {adj. }} F=8.08, p=<$ $\left.0.0001 ; \mathrm{SOC}_{\text {unadj. }} F=7.016, p=0.001\right)$ between fields that had been tilled recently (arable and ley-arable) compared with fields that had not been tilled recently (permanent pasture and woodland) (Table 2).

Correction for clay content also significantly affected calculated SOC stocks for all management types $(p<0.0001$; Figure $1 b)$. Where $\%$ SOC had not been corrected for clay content, the mean SOC stock values were 55.6 t $\mathrm{C} \mathrm{ha}^{-1}$ for arable, $58.2 \mathrm{t} \mathrm{C} \mathrm{ha}^{-1}$ for ley-arable rotation, $71.5 \mathrm{t} \mathrm{C} \mathrm{ha}^{-1}$ for permanent pasture and $72.1 \mathrm{t} \mathrm{C} \mathrm{ha}^{-1}$ for woodland management types. After correction for clay, the mean SOC stock values were $35.0 \mathrm{t} \mathrm{C} \mathrm{ha}^{-1}$ for arable, 41.5 $\mathrm{t} \mathrm{C} \mathrm{ha}^{-1}$ for ley-arable rotation, $55.3 \mathrm{t} \mathrm{C} \mathrm{ha}^{-1}$ for permanent pasture and $54.4 \mathrm{t} \mathrm{C} \mathrm{ha}^{-1}$ for woodland management types. The values for SOC stocks that had been corrected for clay were comparable $(p=0.115)$ to those determined using elemental analysis for the different management types: $38.3 \mathrm{t} \mathrm{C} \mathrm{ha}^{-1}$ for arable, $41.8 \mathrm{t} \mathrm{C} \mathrm{ha}^{-1}$ for ley-arable rotation, $51.6 \mathrm{t} \mathrm{C} \mathrm{ha}^{-1}$ for permanent pasture and $49.8 \mathrm{t} \mathrm{C} \mathrm{ha}^{-1}$. Regardless of correction for clay, the stocks of SOC in the topsoil (2-15 cm depth) were significantly greater in fields under permanent pasture and woodland compared to those under arable or ley-arable rotation $\left(\mathrm{SOC}_{\text {adj. }} F=8.500, p<\right.$ $0.0001 ; \mathrm{SOC}_{\text {unadj. }} F=8.516, p<0.0001 ;$ Figure 1, Table 2) 
Scores for WSA were greater under permanent pasture (mean 7.3, mode 7) and woodland

(mean 7.5, mode 7) than under ley-arable rotation (mean 5.7, mode 6) and arable (mean 5.3,

mode 5) (Table 2) $(p=0.001)$. WSA scores were strongly correlated with SOC content

$\left(\mathrm{SOC}_{\text {adj. }} R^{2}=0.571, p<0.0001 ; \mathrm{SOC}_{\text {unadj. }} R^{2}=0.490, p=0.002\right.$; Figure 3$)$.

\subsection{Effect of time since tillage (TST) on SOC and WSA}

Across all fields sampled, TST ranged from 0.25 to (at least) 100 years, with significant

differences present between arable and ley-arable rotation vs. permanent pasture and

(Table $\mathrm{S} 1, R^{2}=0.70,, p<0.05$ ). Figures $2 \mathrm{a}$ and $2 \mathrm{~b}$ show the linear-log relationships between

$\mathrm{SOC}_{\mathrm{unadj}}$ and $\mathrm{SOC}_{\mathrm{adj}}$, respectively, and time since tillage (y):

288

289

290

291

292

293

294

295

296

297

298

299

300

301

$$
S O C_{\text {unadj }}=56.8+\left(4.66 \times \log _{e}(\mathrm{TST})\right)
$$

Equation 4

where $\mathrm{SOC}_{\text {unadj. }}$ and $\mathrm{SOC}_{\mathrm{adj} .}$ are in $\mathrm{C} \mathrm{ha}^{-1}$ at a depth of 2-15 cm, and TST is in years.

When management and soil variables were combined in multiple linear regression analysis (Table S3), the best predictive model for $\mathrm{SOC}_{\text {unadj. }}$ stocks accounted for $75.5 \%$ of total variation and included $\log _{10}(\mathrm{TST})$ and $\mathrm{TN}$. The equation for the best model was:

$$
S O C_{\text {unadj }}=23.0+\left(6.44 \times \log _{10}(T S T)\right)+(81.7 \times T N)
$$

Equation 6 
The $\mathrm{SOC}_{\mathrm{adj}}$ stock best model contained the same independent variables as above, although the parameter constant values differed as would be expected (Table S4). The best predictive model for WSA included $\log _{10}$ (TST) only, which explained $51.3 \%$ of the observed variation (Table S5):

$$
W S A=5.58+1.26 \times \log _{10}(T S T) \quad \text { Equation } 7
$$

\section{Discussion}

\subsection{Land management changes SOC stocks}

Quantifying the effects of farm management on SOC stocks is critical to realise the potential of agricultural soils to draw down atmospheric $\mathrm{CO}_{2}$ via plants into the soil (sensu Janzen, 2015) and for some of it to be stored in SOM for the long-term, i.e. carbon sequestration. The average \% $\mathrm{SOC}$ recorded for all of the topsoils of the fields of fourteen working farms in southwest England (Devon and Cornwall) $(n=40 ; 5.2 \%)$ was less than the range for the whole of England reported in the 2007 Countryside Survey (7.7\%) which incorporates the random, stratified sampling of soils from managed and unmanaged land classes (Reynolds et al., 2013). The \%SOC in unmanaged habitats reported in the Countryside Survey for England have even larger \%SOC, e.g. $25.8 \%$ in acid grassland, than managed habitats, e.g. $6.8 \%$ in improved grassland. The \%SOC results for improved grassland on Stagni-Vertic Cambisol at Rothamsted Research North Wyke (Rowden Moor, 4.8\%; North Wyke Farm, 5.9\%) in this study are less than the national average, but similar to those reported previously for grassland soil from Rowden Moor by Bol et al. (2003; 5.1\% total carbon by elemental analysis for 4-10 cm depth), Harrod \& Hogan (2008); 5.3\% (calculated from 9.1 \% OM by loss-on-ignition for 5-10 cm depth) and Harris et al. (2018) (6.6\% for 2.5-7.5 cm depth, and 3.6\% for 7.5-15 cm depth, using elemental analysis). The similarity of these published results from the long-term 
Rowden plots at North Wyke established in 1987 with those measured using the same protocols in this study provide confidence in the reliability of the sampling and analysis of the farm soils herein.

Within a defined area in southwest England on farms selected based on similar soil type using available soil survey maps, we observed that the mean \%SOC in topsoil on the farms sampled was largest in woodlands, followed by permanent pasture, then ley-arable rotation, and finally arable fields. However, there were only significant differences overall between recently tilled (i.e. ley-arable rotation and arable) and not recently tilled (i.e. permanent pasture and woodland) management types. We also observed a similar pattern in a subsequent study in May 2017 using the same approach on eight farms in the South Cotswolds on a different soil type (shallow, calcareous, stony soils; Smale et al., 2017; Dungait et al., 2019; Table S6). Our survey, therefore, showed similar patterns related to management type reported by others based on the Countryside Survey 2007 for Great Britain; for instance, the mean SOC stock in $0-15 \mathrm{~cm}$ depth was $63 \mathrm{t} \mathrm{C} \mathrm{ha}^{-1}$ and ranged between $43 \mathrm{t} \mathrm{C} \mathrm{ha}^{-1}$ in arable soils to $82 \mathrm{t} \mathrm{C} \mathrm{ha}^{-1}$ in acid grassland soils (Norton et al., 2012). Comparison with the most relevant Broad Habitats from the Countryside Survey 2007 give mean carbon concentrations of 3.8\% \pm 1.24 for Arable and Horticultural Broad Habitat, $6.8 \% \pm 0.95$ for Improved Grassland and 13.0\% \pm 1.89 for Broadleaf, Mixed and Yew Woodland. Subsequently, we used the GPS coordinates for each field sampled in our research as search criteria for obtaining comparative data using the UK Soil Observatory (UKSO) Map Viewer (www.ukso.org/). Not surprisingly, in many cases, the data associated with Broad Habitat definition did not relate to the management type at the field scale, so the soil data could not be compared directly with that measured in this study. However, it could be used to provide a regionally appropriate range of values for comparison: Arable and Horticultural Broad 
352

353

354

355

356

357

358

359

360

361

362

363

364

365

366

367

368

369

370

371

372

373

374

375

376

Habitat, 2.1-3.5\% (49.67 t C ha-1); Improved Grassland, 4.9-6.3\% (72.14 t C ha-1); and Broadleaf, Mixed and Yew Woodland, 8.1\% (68.53 t C ha-1). The \%SOC and carbon stocks calculated for our samples were smaller because they excluded the top 0-2 cm which is generally richer in organic matter derived directly from plant litter and other organic inputs, e.g. manures (Bol et al., 2003; Dungait et al., 2005; Harris et al., 2018). Again, the similarity with the published values from the Countryside Survey 2007 that are local to the sample sites on farms in our survey provides confidence that the similar protocols applied are reliable to measure SOC stocks in different management types.

Overall, our study using real farm soils concurs with the outputs of other UK experimental studies that reported predictable changes in SOC stocks after land-use change in agriculture (King et al., 2004; Bhogal et al., 2009). It further reinforces the evidence that changes in SOC can be measured in agricultural soils using widely available technologies established and proven for topsoils across management types in the national soil surveys in England and Wales and Scotland, provided they are applied in an informed way with due consideration to the known sources of error (Henrys et al., 2012; Lilly et al., 2012; Seaton et al., 2020; Thomas et al., 2020). On that premise, and based on our small surveys of SOC under different management on real farms in the Tamar Valley and the South Cotswolds, we accept our overarching hypothesis that variations in SOC stocks in agricultural soils can be measured and related to land management.

Undoubtedly, soil texture (or 'physiotope' sensu Verheijen et al., 2005) is of paramount importance as our analysis with and without correction for clay has shown (Figure 1). The search for a dependable correction factor to account for the structural water held by clay minerals to avoid overestimating SOM content calculated during heating in loss-on-ignition 
has preoccupied soil scientists for decades (e.g. Ball, 1964; Howard \& Howard, 1990; Jensen et al., 2018). However, this study shows that by applying simple parameters for sampling 'like with like' based on the use of soil maps and farmer knowledge to select similar sampling points, intra- and inter-farm comparisons of soil variables are possible. This result goes against the apparent misgivings about whether SOC can be measured meaningfully on farmed soils because in-field variation is too great, and indicates a need for a broader view on the evidence required for rewarding farmers for carbon sequestration.

\subsection{Time since tillage controls SOC stocks}

Managing farmed soils to increase and maintain SOC at optimal levels while producing food is an economically and environmentally virtuous activity (Lal, 2020). Soil sink saturation, i.e. the time taken for soil carbon to reach a new equilibrium, when there is no net uptake of carbon from the atmosphere (Smith, 2005), is the ultimate aim for enabling maximum benefit of $\mathrm{CO}_{2}$ drawdown into soil. However, although cultivated soils are unlikely ever to reach the limit of their potential to sequester carbon because any form of perturbation through cultivation will reduce SOC stocks, increasing soil carbon per se has indirect benefits that reduce the overall carbon footprint of agriculture (Paustian et al., 2019).

We determined that time since tillage was a strong predictor of SOC stocks (and of the stability of soil macroaggregates in water; discussed below), and that conclusion helped to explain the variation in carbon stock values observed within different broad land-use types on individual farms. Soil carbon accumulation after a land-use change from arable to grasslands or woodland is a decadal process (Ostle et al., 2009), and, therefore, requires land management matched to reward systems that acknowledge this timescale of commitment. Recognising when the soil has reached sink capacity should rely on data sets that extend to 
these timescales, but these are scarce and especially rare for on-farm studies. Furthermore, the measurement of SOC/SOM is not a regular part of soil testing and has only recently been added to extra 'soil health' options offered by commercial testing laboratories. Since the capacity to measure SOC in the same farm soil over decades was not possible, working with farmers to determine the last tillage event in specific fields in soils of similar soil texture in a region of southwest England under the same climatic conditions enabled us to develop a 'space-for-time' chronosequence of SOC change.

Fields tilled within the last 3 years (all under arable and arable-ley rotation) had smaller carbon stocks than those not tilled for more than 3 years (all under permanent pasture or woodland management), and continuous tillage maintained SOC at a poorer level. The fields under ley-arable rotation were either in grass at the time of sampling or had been ploughed out of grass between 0 and 3 years ago, with most farmers using 3-5-year ley periods before 2-5 years of arable cropping. Regular ploughing even at extended timescales prevented SOC from reaching its maximum potential storage capacity. This observation is similar to the outputs of long-term experiments where management type management has been changed and SOC dynamics monitored over time (Bhogal et al., 2009). It is well known that the potential to increase SOC depends on soil type (e.g. it is more difficult to increase and maintain SOC in very sandy soils) and its current SOC content; SOC cannot be increased in soils that have reached their maximum SOC content or 'sink saturation' (Stewart et al., 2007). Experimental 3-year grass or grass-clover periods in 5-year rotations increased the $\%$ SOC of sandy-loam topsoil $(0-25 \mathrm{~cm})$ by only $0.25 \%$ over 28 years in eastern England (Johnston et al., 2017). Although the size of our dataset did not allow us to confidently model the threshold of maximum carbon storage on the farms in this study, we tentatively conclude that a period of more than 30 years is required without tillage for SOC to build in topsoils 
from the equilibrium maintained by annual, arable tillage to that of permanent pasture and woodland (Figure 2). Farmers who have land with optimum SOC, for the soil type and climate conditions, i.e., have reached soil sink saturation, should, therefore, be rewarded for its maintenance.

\subsection{Aggregate stability in water can be used as a proxy for SOC}

Proxies for SOC are increasingly sought to provide tools for farmers to make judgements about the effect of changes that they have made on their farm to build SOC without the need for laboratory testing. Those indicating 'soil health' must, by definition, explicitly encompass the role of soil biology because the soil is a living ecosystem. This idea underpins the premise for soil health indicators that are largely based on biological attributes of soil quality described by Gregorich et al. (1997) more than 20 years ago. The quality of soil 'tilth' and its relationship with aggregate shape and dry aggregate stability underpins the widely used VESS method for the assessment of agricultural soils (Guimarães et al., 2011). The relationship between the stability of aggregates in water (or the 'slake test') and SOC is particularly pertinent in managed soils with large clay contents because the dispersion of clays is associated with reduced infiltration and run-off, sediment load and crust formation (Watts \& Dexter, 1997). However, the soil-binding qualities of clay also serve to stabilise aggregates and may, thereby, confound an observable and measurable effect of SOC as both a direct binding agent (Martens, 2000) and an indirect binding agent because it supports the function of the soil biological community by providing a large and moist surface area in water films around clay particles that are often protected within aggregates (Dungait et al., 2018). Indeed, Johannes et al. (2017) recently developed an index of soil structural quality using the ratio of SOC:clay applied to Swiss arable soils intended to support on-farm decision making, which has been applied recently by Soinne et al. (2020) and Prout et al. (2020) to 
farmed soils in Finland and the UK, respectively; the latter used the SOC data provided by the Countryside Survey of England and Wales in 1987.

The results of linear regression indicated that time since tillage was a strong driver of both SOC and WSA and that SOC and WSA were closely related. Like SOC stocks, the stability of soil aggregates in water in arable and arable-ley rotation soils was typically less than in grassland and woodland (Table 2). The relationship between SOC and improved physical quality of soil, and subsequent benefits for the quality of farmed soils is widely acknowledged (Dungait et al., 2012; Paustian et al., 2019). In a long-term experiment in northern Sweden, Jarvis et al. (2007) observed that treatments with longer ley periods $(<5$ years) in a 6-year rotation had soils with smaller bulk densities and larger porosities coincident with larger organic carbon contents.

It is well understood that organic carbon improves soil aggregation resulting in increased soil porosity, improving mechanical resilience to compression and the rebound or resilience to compressive stress (Zhang et al., 2005). Soil aggregate stability is partially derived from SOC because of the cohesive effects of organic molecules, and because SOC sustains soil organisms which are agents of aggregation; thus, SOC lost by mineralization must be replaced by new organic carbon to maintain stable aggregates (Dungait et al., 2018). In this respect, soil aggregates are a good proxy for the combined physical, chemical and biological functioning of the soil. In this paper, the potential to use an existing test of the stability of soil aggregates in water, used widely in the USA for many years, was tested and adapted to the specific conditions of the clay-rich soils of the Tamar Valley. The scoring protocol, with more time intervals than the existing USDA version, appeared to satisfactorily improve the sensitivity of the test without compromising the feasibility of its application by land 
managers. The strong relationships between WSA, SOC, land management and time since tillage suggests that where soil and climate on farms is similar within a defined region, the rapid assessment of WSA using this approach provides a rapid and inexpensive means of assessing and providing a numerical score of 'soil health', and potentially as a proxy for direct measurement of SOC used to detect changes imposed by management.

\subsection{Relevance of this study to policy}

Like most businesses, farming is based on maximising net economic returns and requires incentivisation to change practice. The direct economic benefits of increasing SOC in farmland in the UK for the award of rural payments seem clear. The current EU Good Agricultural and Environmental Conditions (GAEC) standards set cross-compliance baseline requirements for farmers to safeguard soils, habitats and landscape features. GAEC 6 directly specifies 'Maintaining the level of organic matter in soil' by avoiding practices that reduce SOM (Defra, 2018a), indirectly ensuring the delivery of GAEC 4 (Providing minimal soil cover) and GAEC 5 (Minimising soil erosion). Soil policy documents over the past decade for the UK have emphasised the need to protect and enhance soil carbon stocks (Minasny et al., 2017). The recent Government 25-Year Environment Plan for England and Wales (Defra, 'ensure healthier soils by addressing factors in soil degradation such as erosion, compaction and the decline in organic matter' and 'protecting and improving the quality of soil'. Yet, despite the central role of managing SOC in these fundamental and enforced requirements, guidance on the appropriate methods to measure SOC is not explicit. As 'protecting and improving the quality of soil' is now overtly mentioned in the new Agriculture Bill for England (https://services.parliament.uk/bills/2019-20/agriculture.html), we assume that good 
502

503

504

505

506

507

508

509

510

511

512

513

514

515

516

517

518

519

520

521

522

523

524

525

526

Management (ELM) scheme that will pay farmers and land managers for providing environmental benefits: clean air, clean water, reductions in environmental hazards and pollution, thriving plants and wildlife, enhanced landscapes and mitigation and adaptation measures to minimise the impact of climate change (DEFRA, 2019). The findings of this study suggest that the use of simple and well-established technologies to, directly and indirectly, quantify SOC as a primary soil health indicator and mechanism for carbpn sequestration are both possible and deliverable within the UK farming industry.

\section{Conclusion}

The dearth of relevant studies of SOC stocks in working agricultural soils, to draw on for robust data comparison to inspire confidence in farmers and land managers to change practice, creates a fundamental problem can be only addressed by appropriate research and investment in partnership with farmers. This study was designed to begin to address the need for good quality data from working farms related to the measurement of SOC using similar protocols to those used in the UK Countryside Survey, and its relationship with a recognised soil health indicator used widely in the USA (the 'slake test') by comparing topsoils from different management on the same soil type. We measured SOC contents in arable, leyarable, permanent pasture and woodland soils, and these bore close comparison to published values for similar land-use types in the region. Recently tilled soils (arable and ley-arable) were significantly poorer in SOC than those cultivated more than 3 years ago, and SOC tended to increase with time since tillage to equilibrium after at least 30 years. Although the relationship between TST and raw \%SOM data was strong, correcting for clay content and bulk density improved the relationship further. Our first major conclusion is that SOC can be reliably measured in farmed soils using accepted protocols and related to land management, and that the database of on-farm measurements should be rapidly augmented to reward 
farmers for sustainable soil management (and carbon sequestration should a reliable carbon market emerge).

529

530 The soils selected by this study had large clay contents, and the tendency for clay minerals to 531 form soil aggregates may have reduced the sensitivity of the 'slake test'. The stability of aggregates in water scored using a slightly adapted version of the USDA protocol with more time intervals was used satisfactorily to separate aggregates from different management types. Furthermore, the WSA scores were directly related to SOC content and TST indicating that the stability of aggregates from topsoil in water could be used as a simple test by farmers to monitor changes in their soils after management changes, and to tentatively assess SOC and soil health, because maintaining SOC is necessary for the stability of aggregates since it supports the biological agents of soil aggregation. Therefore, our second conclusion is that WSA scores can be rapidly measured in clay soils and related to SOC stocks and soil management by land managers and should be included in the development of soil health toolkits for farmers currently under discussion by policymakers and industry.

Acknowledgements

Special thanks are given to the farmers of the Tamar Valley Organic Group (TVOG) who precipitated in the development of the project and participated as case study farms. We thank the Westcountry Rivers Trust for providing funding for TB and for soil sampling and analysis

547 in the laboratories at North Wyke, and Tim Harrod and David Hogan (formerly Soil Survey of England and Wales) for help with the development of the soil sampling technique and training. SC and MJ were supported in part by the National Institute of Food and Agriculture, U.S. Department of Agriculture, under award number 2013-68002-20525, and SMC travel was funded by the Global Farm Platform project (www.globalfarmplatform.org). JD was 
552 funded by BBSRC-funded institute strategic programme (2012-2017) at Rothamsted

553 Research on Maximising Carbon Retention in Soils (BBS/E/C/00005214).

554

555 Authorship

$556 \mathrm{JD}, \mathrm{AI}, \mathrm{HK}$ and MJ conceived the project; SC and JD designed the survey; SC and TB

557 carried out the fieldwork; SC, TB, JD and DH carried out the laboratory analysis; SG, SC and

558 JD analysed the data; SC and JD wrote the first draft and all authors contributed to the final

559 version of the paper.

560

561 Conflict of Interest Statement

562 The authors declare no conflict of interest.

563 


\section{References}

Ball, D.F., 1964. Loss-on-ignition as an estimate of organic matter and organic carbon in non-calcareous soils. Journal of Soil Science, 15, 84-92.

Ball, B.C., Batey, T. and Munkholm, L.J., 2007. Field assessment of soil structural quality-a development of the Peerlkamp test. Soil Use and Management, 23, 329-337.

Bhogal, A., Nicholson, F.A. and Chambers, B.J., 2009. Organic carbon additions: effects on soil bio-physical and physico-chemical properties. European Journal of Soil Science, 60, 276286.

Bol, R., Moering, J., Kuzyakov, Y. and Amelung, W., 2003. Quantification of priming and $\mathrm{CO}_{2}$ respiration sources following slurry-C incorporation into two grassland soils with different C content. Rapid Communications in Mass Spectrometry, 17, 2585-2590.

Chapman, S.J., Bell, J.S., Campbell, C.D., Hudson, G., Lilly, A., Nolan, A.J., Robertson, A.H.J., Potts, J.M. and Towers, W., 2013. Comparison of soil carbon stocks in Scottish soils between 1978 and 2009. European Journal of Soil Science, 64, 455-465.

Christensen, B.T. and Johnston, A.E., 1997. Soil organic matter and soil quality-lessons learned from long-term experiments at Askov and Rothamsted. In Developments in Soil Science, 25, 399-430).

Collier, S.M., Ruark, M.D., Naber, M.R., Andraski, T.W. and Casler, M.D. 2017. Apparent stability and subtle change in surface and subsurface soil carbon and nitrogen under a longterm fertilizer gradient. Soil Science Society of America Journal, 81, 310-321.

Davies, B.E., 1974. Loss-on-ignition as an estimate of soil organic matter 1. Soil Science Society of America Journal, 38, 150-151.

DEFRA (2018a) The Guide to Cross Compliance 2018. https://assets.publishing.service.gov.uk/government/uploads/system/uploads/attachment_data /file/668684/Cross_Compliance_2018_guide_v1.0.pdf, p. 27-29.

DEFRA (2018b) A Green Future: Our 25 year Plan to Improve The Environment. https://assets.publishing.service.gov.uk/government/uploads/system/uploads/attachment_data /file/693158/25-year-environment-plan.pdf, p.43.

DEFRA (2019) Farming is Changing: Here's What You Need to Know. https://assets.publishing.service.gov.uk/government/uploads/system/uploads/attachment_data /file/826341/future-farming-leaflet-august-2019.pdf, pp. 8.

de Gruijter, J.J., McBratney, A.B., Minasny, B., Wheeler, I., Malone, B.P. and Stockmann, U., 2018. Farm-scale soil carbon auditing. Pedometrics, 693-720.

Doran, J. W., \& Parkin, T. B. (1997). Quantitative indicators of soil quality: a minimum data set. Methods for assessing soil quality, 49, 25-37. 
Dungait, J.A.J., Bol, R. and Evershed, R.P., 2005. Quantification of dung carbon incorporation in a temperate grassland soil following spring application using bulk stable carbon isotope determinations. Isotopes in Environ Health Studies, 41, 3-11.

Dungait, J.A.J., Cardenas, L.M., Blackwell, M.S., Wu, L., Withers, P.J., Chadwick, D.R., Bol, R., Murray, P.J., Macdonald, A.J., Whitmore, A.P. and Goulding, K.W. (2012). Advances in the understanding of nutrient dynamics and management in UK agriculture. Science of the Total Environment, 434, 39-50.

Dungait, J.A.J, Berhe, A.A., Gregory, A.S. and Hopkins, D.W., 2018. Chapter 6 Physical Protection and Mean Residence Time of Soil Carbon. In Soil and Climate (pp. 171-182). CRC Press.

Dungait, J.A.J., Smale C., Collier. S.M., Green, S.M., Inman, A., Jahn, M., Hopkins, D.W. (2019) The importance of soil organic matter for soil structure in grasslands. In Improving grassland performance: managing soil structure and organic matter. Newell-Price, J.P., Jewkes, E. C., Pattinson, S. E. (Eds). Proceedings of the British Grassland Society and British Society of Soil Science Joint Winter Meeting, 19th March 2019, Solihull, UK. p.1-4. ISBN 0 905944429

Dunn, O.J., 1964. Multiple comparisons using rank sums. Technometrics, 6, 241-252.

Gee, G.W. and Bauder, J.W. 1986. Particle-size analysis. In Klute, A. (ed) Methods of Soil Analysis, Part 1. Physical and Mineralogical Methods-Agronomy Monograph No. 9, 2nd edn, pp. 383-411, Amer. Soc. of Agronomy, Soil Sci. Soc. of America, Madison, WI.

Gregorich, E.G., Carter, M.R., Angers, D.A., Monreal, C.M. and Ellert, B., 1994. Towards a minimum data set to assess soil organic matter quality in agricultural soils. Canadian Journal of Soil Science, 74, 367-385.

Gregory, A.S., Dungait, J.A.J., Watts, C.W., Bol, R., Dixon, E.R., White, R.P. and Whitmore, A.P. (2016). Long-term management changes topsoil and subsoil organic carbon and nitrogen dynamics in a temperate agricultural system. European Journal of Soil Science, 67, 421-430.

Guimarães, R.M.L., Ball, B.C., Tormena, C.A., Giarola, N.F.B. and da Silva, Á.P., 2013. Relating visual evaluation of soil structure to other physical properties in soils of contrasting texture and management. Soil and Tillage Research, 127, 92-99.

Harrod, T.R. and Hogan, D.V., 2008. The soils of North Wyke and Rowden. Revised edition of original report by TR Harrod 1981. Soil Survey of England and Wales (now the National Soil Resources Institute, Cranfield University, UK).

Henrys, P.A.; Keith, A.M.; Robinson, D.A.; Emmett, B.A. (2012). Model estimates of topsoil carbon [Countryside Survey]. NERC Environmental Information Data Centre. https://doi.org/10.5285/9e4451f8-23d3-40dc-9302-73e30ad3dd76

Herrick, J.E., Whitford, W.G., De Soyza, A.G., Van Zee, J.W., Havstad, K.M., Seybold, C.A. and Walton, M., 2001. Field soil aggregate stability kit for soil quality and rangeland health evaluations. Catena, 44, 27-35. 
Howard, P.J.A. and Howard, D.M., 1990. Use of organic carbon and loss-on-ignition to estimate soil organic matter in different soil types and horizons. Biology and Fertility of Soils, 9, 306-310.

Jarvis, N.J., 2007. A review of non-equilibrium water flow and solute transport in soil macropores: Principles, controlling factors and consequences for water quality. European Journal of Soil Science, 58, 523-546.

Janzen, H.H., 2015. Beyond carbon sequestration: soil as conduit of solar energy. European Journal of Soil Science, 66, 19-32.

Jensen, J.L., Schjønning, P., Watts, C.W., Christensen, B.T., Peltre, C. and Munkholm, L.J., 2019. Relating soil C and organic matter fractions to soil structural stability. Geoderma, 337, 834-843.

Johnston, A.E., Poulton, P.R., Coleman, K., Macdonald, A.J. and White, R.P., 2017. Changes in soil organic matter over 70 years in continuous arable and ley-arable rotations on a sandy loam soil in England. European Journal of Soil Science, 68, 305-316.

King, J.A., Bradley, R.I., Harrison, R. and Carter, A.D., 2004. Carbon sequestration and saving potential associated with changes to the management of agricultural soils in England. Soil Use and Management, 20, 394-402.

Lal, R., 2016. Soil health and carbon management. Food and Energy Security, 5, 212-222.

Lal, R., 2018. Digging deeper: A holistic perspective of factors affecting soil organic carbon sequestration in agroecosystems. Global Change Biology 24, 3285-3301.

Lal, R., 2020. Managing soils for resolving the conflict between agriculture and nature: The hard talk. European Journal of Soil Science, 71, 1-9.

Lilly, A, Baggaley, N and Donnelly, D. (2012). Map of soil organic carbon in top soils of Scotland. Map prepared for EU project GS-SOIL -Assessment and strategic development of INSPIRE compliant Geodata-Services for European Soil Data. ECP-2008-GEO-318004.

Harris, P., Bol, R., Evans, J., Hawkins, J.M.B., Dixon, E.R., Wolf, K., Dungait, J.A.J., Griffith, B., Herbst, M., Dhanoa, M.S. and Beaumont, D.A., 2018. Effect of long-term drainage on plant community, soil carbon and nitrogen contents and stable isotopic $\left(\delta^{13} \mathrm{C}\right.$, $\left.\delta^{15} \mathrm{~N}\right)$ composition of a permanent grassland. European Journal of Soil Science, 69, 48-68.

Howard, P.J.A., Loveland, P.J., Bradley, R.I., Dry, F.T., Howard, D.M. and Howard, D.C., 1995. The carbon content of soil and its geographical distribution in Great Britain. Soil Use and Management, 11, 9-15.

Johannes, A., Matter, A., Schulin, R., Weisskopf, P., Baveye, P.C. and Boivin, P., 2017. Optimal organic carbon values for soil structure quality of arable soils. Does clay content matter? Geoderma, 302, 14-21. 
Minasny, B., Malone, B.P., McBratney, A.B., Angers, D.A., Arrouays, D., Chambers, A.,

\section{Geoderma, 292, 59-86.}

Norton, L.R., Maskell, L.C., Smart, S.S., Dunbar, M.J., Emmett, B.A., Carey, P.D., Williams, P., Crowe, A., Chandler, K., Scott, W.A. and Wood, C.M. (2012). Measuring stock and change in the GB countryside for policy-key findings and developments from the Countryside Survey 2007 field survey. Journal of Environmental Management, 113, 117-127.

Ostle, N.J., Levy, P.E., Evans, C.D. and Smith, P., 2009. UK management type and soil carbon sequestration. Management type Policy, 26, S274-S283.

Paustian, K. Collier, S., Baldock, J. Burgess, R. Creque, J. DeLonge, M., Dungait, J. Ellert, B. Frank, S. Goddard, T. Govaerts, B., Grundy, M. Henning, M., Izaurralde, C., Madaras, M., McConkey, B., Porzig, E. Rice, C., Searle, R., Seavy, N., Skalsky, R., Mulhern, W. and Jahn, M. (2019) Quantifying carbon for agricultural soil management: from the current status toward a global soil information system. Carbon Management 10, 567-587, DOI: $10.1080 / 17583004.2019 .1633231$

Poulton, P., Johnston, J., Macdonald, A., White, R. and Powlson, D. (2018). Major limitations to achieving " 4 per 1000 " increases in soil organic carbon stock in temperate regions: Evidence from long-term experiments at Rothamsted Research, United Kingdom. Global Change Biology 24, 2563-2584

Prout, J.M., Shepherd, K.D., McGrath, S.P., Kirk, G.J.D. and Haefele, S.M., What is a good level of soil organic matter? An index based on organic carbon to clay ratio. European Journal of Soil Science. doi.org/10.1111/ejss.13012

Reynolds, B., Chamberlain, P.M., Poskitt, J., Woods, C., Scott, W.A., Rowe, E.C., Robinson, D.A., Frogbrook, Z.L., Keith, A.M., Henrys, P.A. and Black, H.I.J., 2013. Countryside Survey: National "Soil Change" 1978-2007 for Topsoils in Great Britain-acidity, carbon, and total nitrogen status. Vadose Zone Journal, 12(2).

Sanderman, J., Hengl, T. and Fiske, G.J., 2017. Soil carbon debt of 12,000 years of human management type. Proceedings of the National Academy of Sciences, 114, 9575-9580

Schjønning, P., Jensen, J.L., Bruun, S., Jensen, L.S., Christensen, B.T., Munkholm, L.J., Oelofse, M., Baby, S. and Knudsen, L., 2018. The role of soil organic matter for maintaining crop yields: Evidence for a renewed conceptual basis. Advances in Agronomy, 150, 35-79. Academic Press.

Schulte, E.E., Kaufmann, C. and Peter, J.B., 1991. The influence of sample size and heating time on soil weight loss-on-ignition. Communications in Soil Science and Plant Analysis, 22, 159-168.

Seaton, F.M., Barrett, G., Burden, A., Creer, S., Fitos, E., Garbutt, A., Griffiths, R.I., Henrys, P., Jones, D.L., Keenan, P. and Keith, A., Online Early View. Soil health cluster analysis based on national monitoring of soil indicators. European Journal of Soil Science. https://doi.org/10.1111/ejss.12958 
Smale, C.E. (2017) The effect of agricultural land management on soil quality in the

Cotswolds, England, assessing the relationship between soil quality indicators for development of a test to estimate soil organic carbon stocks. MSc. Thesis. University of

Smith, P., 2005. An overview of the permanence of soil organic carbon stocks: Influence of direct human-induced, indirect and natural effects. European Journal of Soil Science, 56, 673680 .

Soinne, H., Keskinen, R., Räty, M., Kanerva, S., Turtola, E., Kaseva, J., Nuutinen, V., Simojoki, A. and Salo, T., 2020. Soil organic carbon and clay content as deciding factors for net nitrogen mineralization and cereal yields in boreal mineral soils. European Journal of Soil Science. doi: $10.1111 /$ ejss.13003

Soussana, J.F., Lutfalla, S., Ehrhardt, F., Rosenstock, T., Lamanna, C., Havlík, P., Richards, M., Chotte, J.L., Torquebiau, E., Ciais, P. and Smith, P. (2019). Matching policy and science: Rationale for the ' 4 per 1000-soils for food security and climate' initiative. Soil and Tillage Research, 188, 3-15.

Stewart, C.E., Paustian, K., Conant, R.T., Plante, A.F. and Six, J., 2007. Soil carbon saturation: concept, evidence and evaluation. Biogeochemistry, 86, 19-31.

Stockmann, U., Adams, M.A., Crawford, J.W., Field, D.J., Henakaarchchi, N., Jenkins, M., Minasny, B., McBratney, A.B., De Courcelles, V.D.R., Singh, K. and Wheeler, I., 2013. The knowns, known unknowns and unknowns of sequestration of soil organic carbon.

Agriculture, Ecosystems \& Environment, 164, 80-99.

Thomas, A., Cosby, B.J., Henrys, P. and Emmett, B., 2020. Patterns and trends of topsoil carbon in the UK: Complex interactions of management type change, climate and pollution. Science of The Total Environment, 138330.

Tisdall, J.M. and Oades, J., 1982. Organic matter and water-stable aggregates in soils. European Journal of Soil Science, 33, 141-163.

Verheijen, F.G., Bellamy, P.H., Kibblewhite, M.G. and Gaunt, J.L., 2005. Organic carbon ranges in arable soils of England and Wales. Soil Use and Management, 21, 2-9.

Watts, C.W. and Dexter, A.R., 1997. The influence of organic matter in reducing the destabilization of soil by simulated tillage. Soil and Tillage Research, 42, 253-275. 
801 Table 1 Criteria for scoring soil aggregate stability in water (adapted from Herrick et al.,

$802 \quad 2001)$

\begin{tabular}{|l|l|}
\hline Score & Aggregate behaviour \\
\hline 0 & Soil too unstable to isolate aggregates \\
\hline 1 & $\begin{array}{l}50 \% \text { structural integrity is lost within } 5 \text { seconds of immersion } \\
\text { AND }<10 \% \text { remains after agitation }\end{array}$ \\
\hline 2 & $\begin{array}{l}50 \% \text { structural integrity is lost within } 5-30 \text { seconds of immersion } \\
\text { AND }<10 \% \text { remains after agitation }\end{array}$ \\
\hline 3 & $\begin{array}{l}50 \% \text { structural integrity is lost within } 30-300 \text { seconds of immersion } \\
\text { OR }<10 \% \text { remains after agitation }\end{array}$ \\
\hline 4 & $10-25 \%$ remains after agitation \\
\hline 5 & $25-50 \%$ remains after agitation \\
\hline 6 & $50-75 \%$ remains after agitation \\
\hline 7 & $75-90 \%$ remains after agitation \\
\hline 8 & $>90 \%$ remains after agitation \\
\hline
\end{tabular}

803 
805 Table 2: Mean management and soil variable values by management type and results of analysis of variance (ANOVA), Kruskal-Wallis test and

806 post-hoc comparison

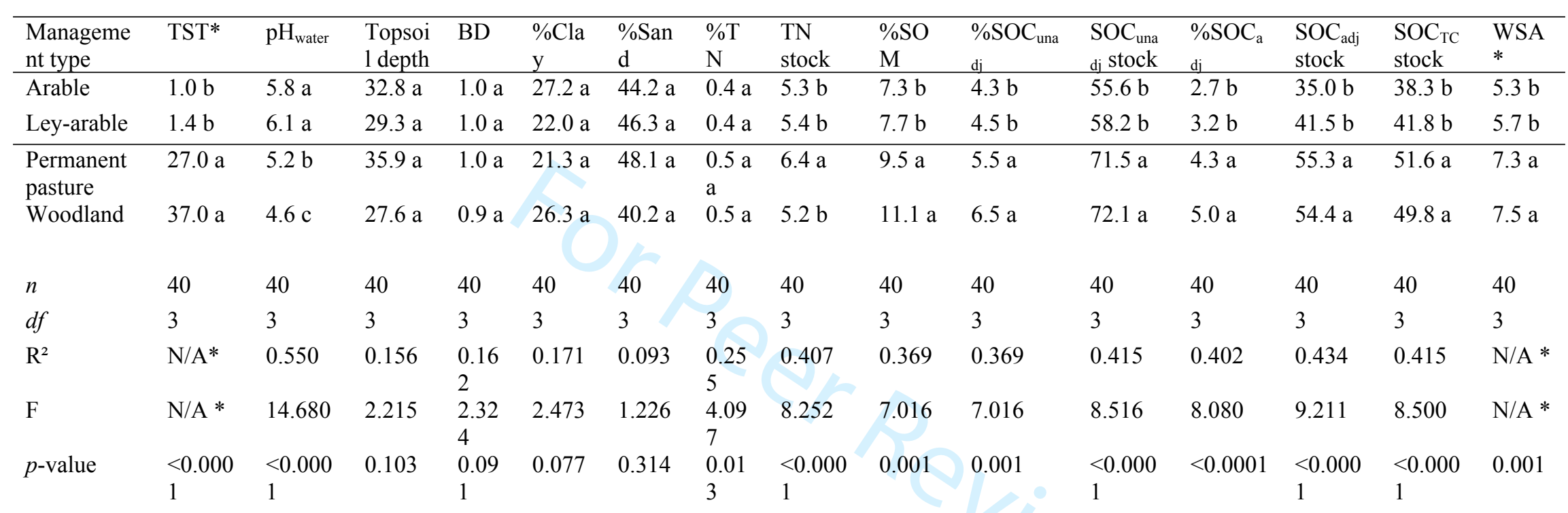

Definitions: TST, time since tillage (y); Topsoil depth, depth of A horizon ( $\mathrm{cm})$; BD, soil bulk density $\left(\mathrm{g} \mathrm{cm}^{-3}\right) ; \%$ SOM, percentage soil organic matter by loss-on-ignition (\% dry matter); \%SOC, percentage soil organic carbon (derived from Equation 1); unadj/adj, uncorrected or corrected for clay content (derived from Equation 2); TC, total

809 carbon by combustion using elemental analyser; stock ( $\mathrm{Mg} \mathrm{C}$ or N ha-1); WSA, stability of aggregates in water, score (Table 1); *Kruskal-Wallis test; values with differing 810 connecting letters in the same column are significantly different at the $\alpha=0.05$ level (Tukey's HSD / Dunn's mean comparison). 


\section{Figure captions}

812

\section{Figure 1}

814 Comparison of calculations of $\%$ SOC. Mean values ( \pm s.e.) for (a) \%SOM (by loss-on-

815 ignition); \% $\% \mathrm{SOC}_{\text {unadj. }}$ (uncorrected for clay content, using equation 2

$816[\% S O C=(\% S O M / 1.72) * 100]) ; \% \mathrm{SOC}_{\mathrm{adj}}$. corrected (corrected for clay content, using

817 Equation $3[\%$ SOC $=(\%$ SOM- $(\%$ clay $* 0.1) / 1.72) * 100]$; and $\% \mathrm{TC}$ (by combustion by

818 elemental analyser).

819

\section{$820 \quad$ Figure 2}

821 Relationship between soil organic carbon $\left(\mathrm{t} \mathrm{C} \mathrm{ha}^{-1}\right)$ (a) uncorrected for clay content: $\mathrm{SOC}_{\text {unadj. }}$

822 and (b) corrected for clay content: $\mathrm{SOC}_{\mathrm{adj}}$ and time since tillage (years). The four

823 management types are identified as follows: arable (O), ley-arable ( $\square$ ), permanent pasture $(\triangle)$

824 and woodland $(\diamond)$.

825

826 Figure 3

827 Box and Whisker plot of mean $(n=3)$ SOC $_{\text {adj }}$ stocks $\left(\mathrm{t} \mathrm{C} \mathrm{ha}^{-1}, 2-15 \mathrm{~cm}\right.$ depth) versus mean $(n$

$828=9)$ aggregate stability of soil macroaggregates $(\sim 1 \mathrm{~cm}$ diameter) in water (WSA) using

829 scoring system (0-8) adapted from Herrick et al. (2001). 
$831 \quad$ Figure 1

832

833

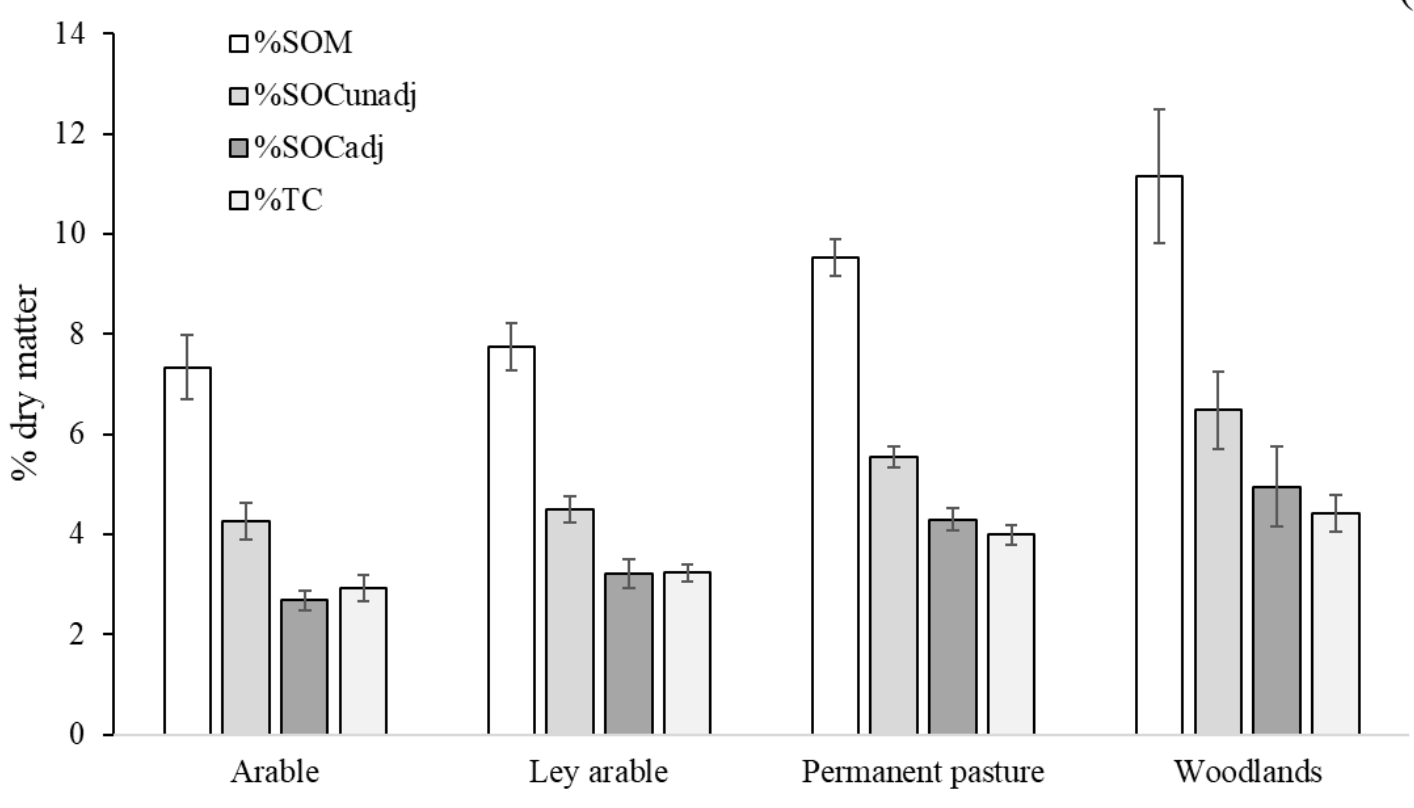

(a)

834

(b)

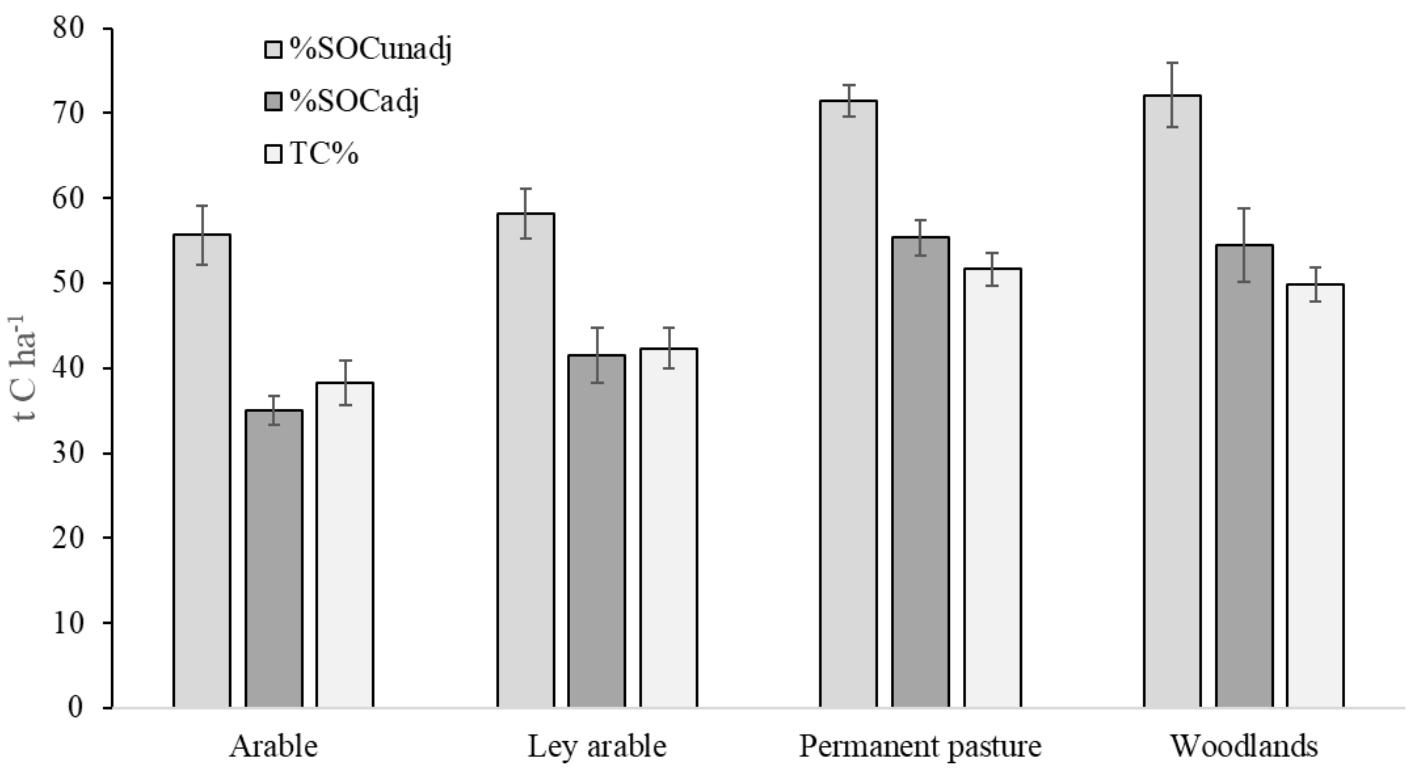


Figure 2

838

(a)

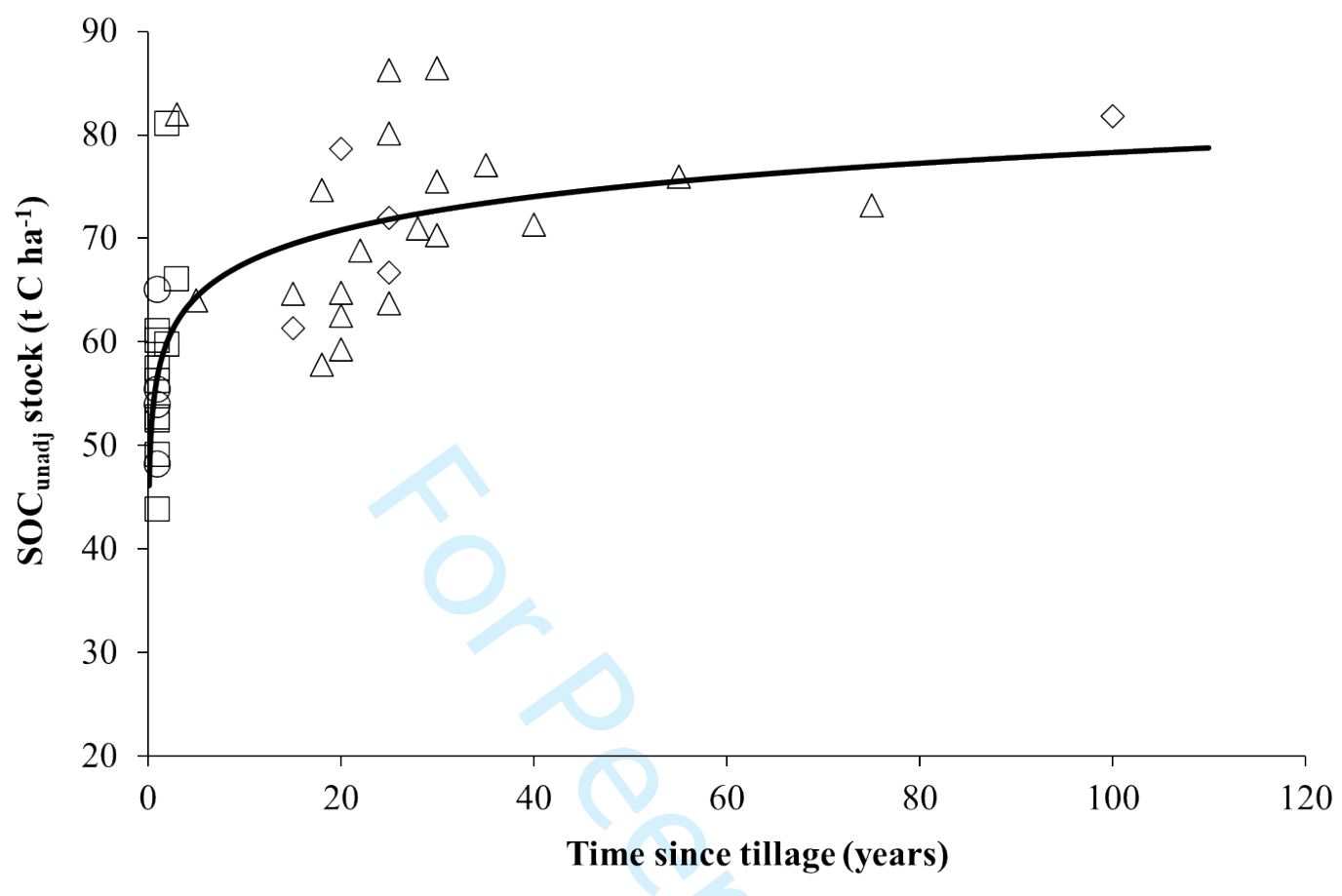

(b)

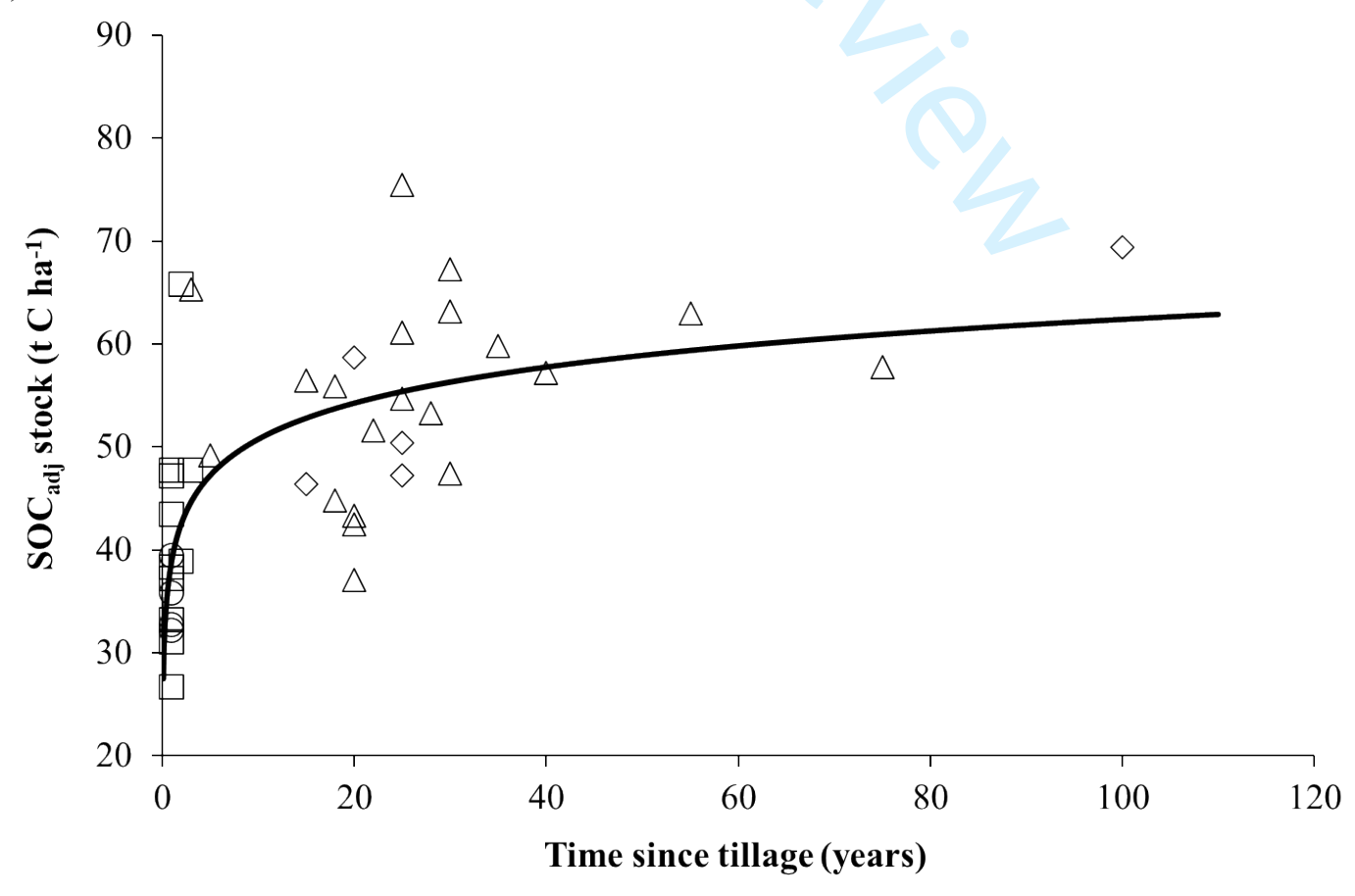


$843 \quad$ Figure 3

844

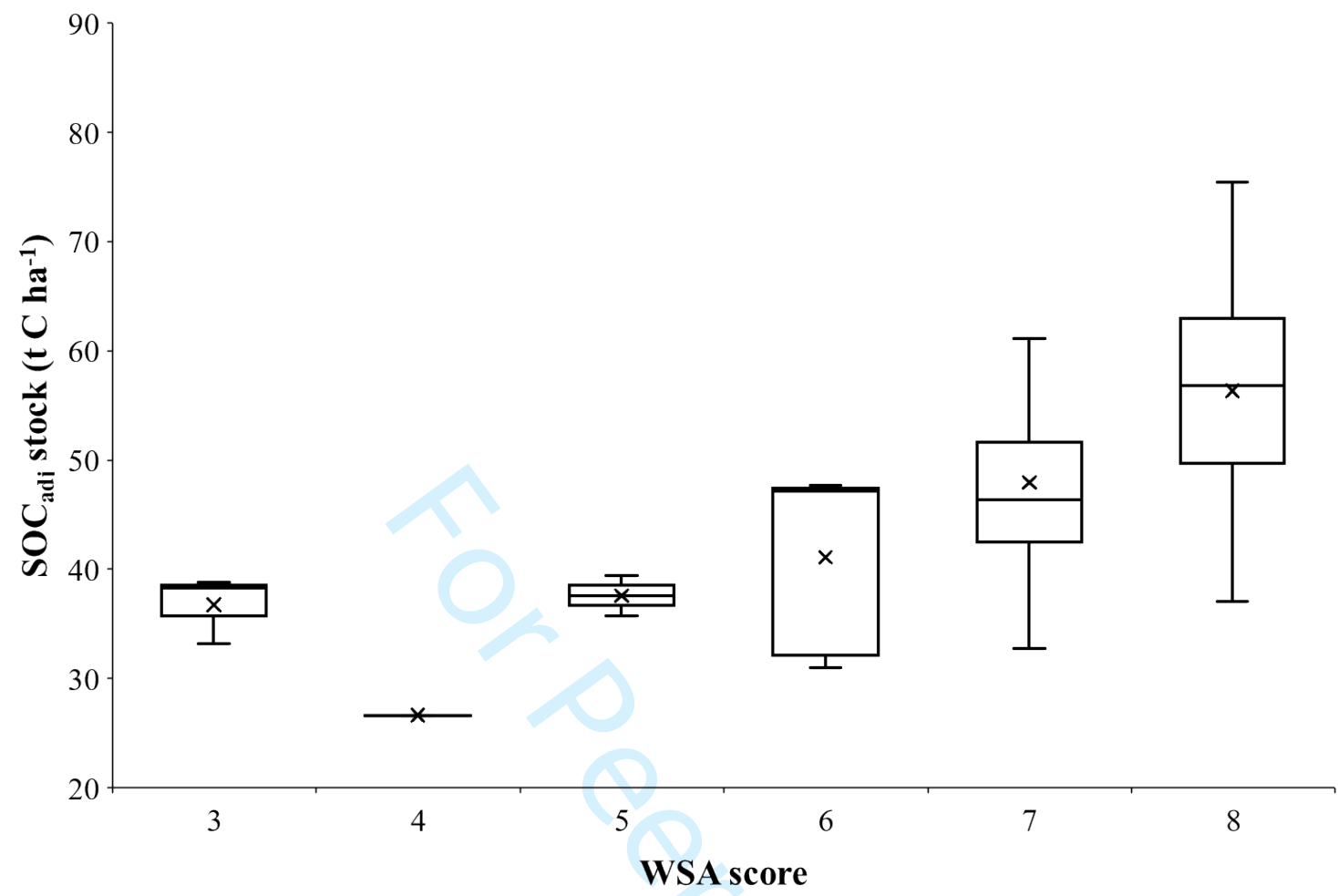

845

846 


\section{Supplementary Material}

848 


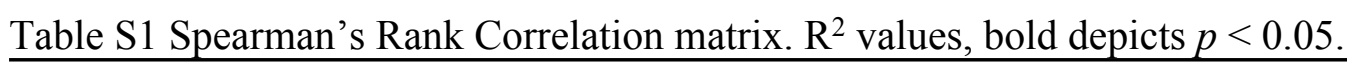

\begin{tabular}{|c|c|c|c|c|c|c|c|c|c|c|c|c|c|c|c|}
\hline Variables & $\mathrm{TST}$ & $\%$ SOM & $\% \mathrm{SOC}_{\text {unadj }}$ & $\begin{array}{l}\mathrm{SOC}_{\text {unadj }} \\
\text { stock }\end{array}$ & WSA & $\mathrm{BD}$ & \%Clay & $\%$ Sand & $\% \mathrm{TN}$ & $\begin{array}{l}\text { TN } \\
\text { stock }\end{array}$ & $\mathrm{pH}_{\text {water }}$ & $\% \mathrm{SOC}_{\mathrm{adj}}$ & $\begin{array}{l}\mathrm{SOC}_{\text {adj }} \\
\text { stock }\end{array}$ & $\begin{array}{l}\mathrm{SOC}_{\mathrm{TC}} \\
\text { stock }\end{array}$ & $\begin{array}{l}\text { Topsoil } \\
\text { depth }\end{array}$ \\
\hline TST & 1.00 & 0.70 & 0.70 & 0.74 & 0.64 & -0.29 & -0.02 & 0.00 & 0.56 & 0.44 & -0.65 & 0.71 & 0.71 & 0.64 & 0.25 \\
\hline$\% \mathrm{SOM}$ & 0.70 & 1.00 & 1.00 & 0.93 & 0.49 & -0.67 & 0.10 & -0.05 & 0.82 & 0.49 & -0.41 & 0.94 & 0.87 & 0.73 & 0.04 \\
\hline$\% \mathrm{SOC}_{\text {unadj }}$ & 0.70 & 1.00 & 1.00 & 0.93 & 0.49 & -0.67 & 0.10 & -0.05 & 0.82 & 0.49 & -0.41 & 0.94 & 0.87 & 0.73 & 0.04 \\
\hline $\mathrm{SOC}_{\text {unadj }}$ stock & 0.74 & 0.93 & 0.93 & 1.00 & 0.55 & -0.37 & 0.02 & 0.03 & 0.77 & 0.63 & -0.40 & 0.92 & 0.94 & 0.82 & 0.04 \\
\hline WSA & 0.64 & 0.49 & 0.49 & 0.55 & 1.00 & -0.13 & -0.21 & -0.05 & 0.47 & 0.40 & -0.63 & 0.57 & 0.60 & 0.71 & 0.23 \\
\hline $\mathrm{BD}$ & -0.29 & -0.67 & -0.67 & -0.37 & -0.13 & 1.00 & -0.21 & 0.17 & -0.53 & 0.02 & 0.25 & -0.56 & -0.33 & -0.20 & -0.02 \\
\hline$\%$ Clay & -0.02 & 0.10 & 0.10 & 0.02 & -0.21 & -0.21 & 1.00 & -0.31 & 0.02 & -0.16 & -0.04 & -0.19 & -0.28 & -0.03 & -0.41 \\
\hline$\%$ Sand & 0.00 & -0.05 & -0.05 & 0.03 & -0.05 & 0.17 & -0.31 & 1.00 & 0.10 & 0.30 & 0.11 & 0.09 & 0.15 & 0.11 & 0.01 \\
\hline$\% \mathrm{TN}$ & 0.56 & 0.82 & 0.82 & 0.77 & 0.47 & -0.53 & 0.02 & 0.10 & 1.00 & 0.78 & -0.31 & 0.79 & 0.73 & 0.70 & 0.16 \\
\hline TN stock & 0.44 & 0.49 & 0.49 & 0.63 & 0.40 & 0.02 & -0.16 & 0.30 & 0.78 & 1.00 & -0.17 & 0.54 & 0.62 & 0.68 & 0.12 \\
\hline $\mathrm{pH}_{\text {water }}$ & -0.65 & -0.41 & -0.41 & -0.40 & -0.63 & 0.25 & -0.04 & 0.11 & -0.31 & -0.17 & 1.00 & -0.42 & -0.37 & -0.41 & -0.07 \\
\hline$\% \mathrm{SOC}_{\mathrm{adj}}$ & 0.71 & 0.94 & 0.94 & 0.92 & 0.57 & -0.56 & -0.19 & 0.09 & 0.79 & 0.54 & -0.42 & 1.00 & 0.96 & 0.76 & 0.17 \\
\hline SOC $_{\text {adj }}$ stock & 0.71 & 0.87 & 0.87 & 0.94 & 0.60 & -0.33 & -0.28 & 0.15 & 0.73 & 0.62 & -0.37 & 0.96 & 1.00 & 0.78 & 0.16 \\
\hline $\mathrm{SOC}_{\mathrm{TC}}$ stock & 0.64 & 0.73 & 0.73 & 0.82 & 0.71 & -0.20 & -0.03 & 0.11 & 0.70 & 0.68 & -0.41 & 0.76 & 0.78 & 1.00 & 0.01 \\
\hline Topsoil depth & 0.25 & 0.04 & 0.04 & 0.04 & 0.23 & -0.02 & -0.41 & 0.01 & 0.16 & 0.12 & -0.07 & 0.17 & 0.16 & 0.01 & 1.00 \\
\hline
\end{tabular}


853 Table S2 Management characteristics and soil properties of sample sites.

\begin{tabular}{|c|c|c|c|c|c|c|}
\hline Farm no. & Management type & $\begin{array}{l}\text { Topsoil } \\
\text { depth }\end{array}$ & Soil texture & $\mathrm{BD}$ & $\mathrm{pH}$ & $\mathrm{TN}(\%)$ \\
\hline & & $\mathrm{cm}$ & sand:silt:clay & $\mathrm{g} \mathrm{cm}^{3}$ & & $\%$ \\
\hline 1 & Permanent pasture & 26 & $31: 41: 28$ & $1.05(0.035)$ & $4.36(0.114)$ & 0.402 \\
\hline 1 & Woodland & 18 & $34: 39: 27$ & $0.94(0.100)$ & $3.83(0.142)$ & 0.448 \\
\hline 2 & Permanent pasture & 26 & $52: 23: 25$ & $0.98(0.016)$ & $4.45(0.115)$ & 0.525 \\
\hline 2 & Woodland & 33 & $37: 31: 31$ & $0.91(0.032)$ & $4.34(0.385)$ & 0.427 \\
\hline 3 & Permanent pasture & 34 & $36: 43: 20$ & $1.00(0.028)$ & $4.17(0.162)$ & 0.479 \\
\hline 3 & Permanent pasture & 40 & $48: 36: 16$ & $1.10(0.070)$ & $4.50(0.095)$ & 0.375 \\
\hline 4 & Arable & 39 & $56: 19: 26$ & $1.01(0.062)$ & $6.01(0.056)$ & 0.418 \\
\hline 4 & Permanent pasture & 36 & $56: 24: 21$ & $1.09(0.013)$ & $4.52(0.215)$ & 0.531 \\
\hline 4 & Permanent pasture & 56 & $53: 27: 20$ & $0.95(0.065)$ & $4.37(0.127)$ & 0.505 \\
\hline 5 & Permanent pasture & 40 & $51: 37: 12$ & $0.98(0.028)$ & $4.13(0.087)$ & 0.447 \\
\hline 5 & Ley-arable rotation & 38 & $48: 32: 20$ & $0.95(0.062)$ & $5.01(0.223)$ & 0.455 \\
\hline 5 & Woodland & 35 & $49: 29: 22$ & $0.90(0.042)$ & $3.57(0.221)$ & 0.504 \\
\hline 6 & Permanent pasture & 22 & $51: 21: 28$ & $0.92(0.047)$ & $4.56(0.044)$ & 0.643 \\
\hline 6 & Ley-arable rotation & 28 & $53: 25: 21$ & $0.97(0.048)$ & $5.18(0.066)$ & 0.402 \\
\hline 7 & Permanent pasture & 30 & $57: 33: 10$ & $1.14(0.017)$ & $4.85(0.050)$ & 0.428 \\
\hline 7 & Ley-arable rotation & 25 & $44: 40: 15$ & $1.09(0.082)$ & $4.97(0.075)$ & 0.414 \\
\hline 8 & Permanent pasture & 33 & $53: 29: 18$ & $0.94(0.069)$ & $4.62(0.307)$ & 0.524 \\
\hline 8 & Ley-arable rotation & 30 & $35: 36: 29$ & $0.81(0.202)$ & $5.49(0.012)$ & 0.448 \\
\hline 9 & Permanent pasture & 42 & $47: 29: 24$ & $1.05(0.027)$ & $4.06(0.194)$ & 0.460 \\
\hline 9 & Arable & 32 & $50: 30: 20$ & $1.05(0.081)$ & $4.33(0.068)$ & 0.349 \\
\hline 10 & Ley-arable rotation & 21 & $60: 17: 22$ & $1.08(0.014)$ & $4.78(0.104)$ & 0.440 \\
\hline 10 & Ley-arable rotation & 20 & $55: 19: 26$ & $0.99(0.082)$ & $5.22(0.021)$ & 0.405 \\
\hline 10 & Permanent pasture & 30 & $59: 16: 25$ & $0.99(0.052)$ & $4.42(0.104)$ & 0.522 \\
\hline 10 & Woodland & 17 & $50: 24: 26$ & $1.00(0.039)$ & $4.91(0.332)$ & 0.386 \\
\hline 10 & Ley-arable rotation & 35 & $45: 31: 25$ & $1.13(0.019)$ & $6.91(0.012)$ & 0.377 \\
\hline 10 & Ley-arable rotation & 28 & $56: 24: 20$ & $0.92(0.083)$ & $5.77(0.160)$ & 0.411 \\
\hline 10 & Permanent pasture & 25 & $49: 23: 28$ & $1.06(0.029)$ & $4.62(0.104)$ & 0.416 \\
\hline 11 & Ley-arable rotation & 33 & $36: 43: 21$ & $0.94(0.148)$ & $4.87(0.119)$ & 0.532 \\
\hline 11 & Permanent pasture & 34 & $49: 35: 16$ & $0.89(0.102)$ & $4.74(0.106)$ & 0.735 \\
\hline 12 & Permanent pasture & 35 & $50: 28: 22$ & $1.02(0.071)$ & $5.00(0.053)$ & 0.618 \\
\hline 12 & Ley-arable rotation & 32 & $36: 43: 21$ & $1.11(0.013)$ & $5.91(0.180)$ & 0.367 \\
\hline 12 & Ley-arable rotation & 32 & $42: 37: 21$ & $1.09(0.016)$ & $6.21(0.080)$ & 0.330 \\
\hline 13 & Permanent pasture & 59 & $40: 42: 18$ & $0.91(0.021)$ & $4.86(0.233)$ & 0.471 \\
\hline 13 & Permanent pasture & 53 & $53: 23: 23$ & $1.00(0.038)$ & $4.75(0.093)$ & 0.476 \\
\hline 13 & Woodland & 35 & $32: 44: 25$ & $0.66(0.057)$ & $3.34(0.116)$ & 0.506 \\
\hline 14 & Permanent pasture & 34 & $45: 37: 18$ & $1.07(0.086)$ & $4.66(0.123)$ & 0.388 \\
\hline 14 & Permanent pasture & 32 & $43: 34: 22$ & $1.02(0.025)$ & $4.76(0.168)$ & 0.506 \\
\hline 15 & Permanent pasture & 30 & $39: 29: 32$ & $0.96(0.045)$ & $4.17(0.078)$ & 0.475 \\
\hline 15 & Arable & 35 & $43: 30: 28$ & $1.04(0.082)$ & $4.95(0.095)$ & 0.387 \\
\hline 15 & Arable & 25 & $28: 36: 36$ & $0.94(0.093)$ & $4.83(0.112)$ & 0.480 \\
\hline
\end{tabular}


Table S3: Multiple Linear Regression: $\mathrm{SOC}_{\text {unadj }}$ stock (Mg SOC ha-1)

857

\begin{tabular}{|l|l|l|l|l|l|}
\hline $\begin{array}{l}\text { No. of } \\
\text { variables }\end{array}$ & Variables & MSE & $\mathrm{R}^{2}$ & $\begin{array}{l}\text { Adjusted } \\
\mathrm{R}^{2}\end{array}$ & $\begin{array}{l}\text { Akaike's } \\
\text { AIC }\end{array}$ \\
\hline 1 & Total N (\%) & 45.778 & 0.623 & 0.613 & 154.901 \\
\hline $\mathbf{2}$ & Log $_{10}$ TST (y) / Total N & $\mathbf{3 0 . 5 2 3}$ & $\mathbf{0 . 7 5 5}$ & $\mathbf{0 . 7 4 2}$ & $\mathbf{1 3 9 . 6 2 1}$ \\
\hline 3 & WSA / Log 10 TST (y) / Total N (\%) & 30.852 & 0.759 & 0.739 & 140.954 \\
\hline
\end{tabular}

858

\begin{tabular}{|l|l|l|l|l|l|}
\hline Source & DF & $\begin{array}{l}\text { Sum of } \\
\text { squares }\end{array}$ & $\begin{array}{l}\text { Mean } \\
\text { squares }\end{array}$ & F & $p$-value \\
\hline Model & 2 & 3479.048 & 1739.524 & 56.990 & $<\mathbf{0 . 0 0 0 1}$ \\
\hline Error & 37 & 1129.355 & 30.523 & & \\
\hline $\begin{array}{l}\text { Corrected } \\
\text { Total }\end{array}$ & 39 & 4608.403 & & & \\
\hline
\end{tabular}

860 Model parameters:

\begin{tabular}{|l|l|l|l|l|l|l|}
\hline Source & Value & $\begin{array}{l}\text { Standard } \\
\text { error }\end{array}$ & T & p-value & Lower bound (95\%) & Upper bound (95\%) \\
\hline Intercept & 23.045 & 5.257 & 4.383 & $<\mathbf{0 . 0 0 0 1}$ & 12.393 & 33.697 \\
\hline $\log _{10}$ TST $(y)$ & 6.438 & 1.440 & 4.471 & $<\mathbf{0 . 0 0 0 1}$ & 3.520 & 9.355 \\
\hline Total N (\%) & 81.660 & 12.219 & 6.683 & $<\mathbf{0 . 0 0 0 1}$ & 56.901 & 106.418 \\
\hline
\end{tabular}


867

869

868 Model parameters:

Table S4: Multiple Linear Regression: $\mathrm{SOC}_{\text {adj }}$ stock (Mg SOC ha-1)

\begin{tabular}{|l|l|l|l|l|l|}
\hline No. variables & Variables & MSE & $\mathrm{R}^{2}$ & $\begin{array}{l}\text { Adjusted } \\
\mathrm{R}^{2}\end{array}$ & $\begin{array}{l}\text { Akaike's } \\
\text { AIC }\end{array}$ \\
\hline 1 & Total N (\%) & 58.773 & 0.600 & 0.590 & 164.896 \\
\hline 2 & Log $_{10}$ TST (y) / Total N (\%) & 40.708 & 0.730 & 0.716 & 151.138 \\
\hline $\mathbf{3}$ & WSA* / Log10TST (y) / Total N (\%) $_{\mathbf{3 8 . 2 9 1}}$ & $\mathbf{0 . 7 5 3}$ & $\mathbf{0 . 7 3 3}$ & $\mathbf{1 4 9 . 5 9 4}$ \\
\hline
\end{tabular}

* Based on the Type III sum of squares, WSA does not bring significant information to explain the variability the dependent variable $\mathrm{SOC}_{\mathrm{adj}}$ stock.

Analysis of variance (SOC stock clay):

\begin{tabular}{|l|l|l|l|l|l|}
\hline Snalysis of variance (SOC stock clay): & DF & $\begin{array}{l}\text { Sum of } \\
\text { squares }\end{array}$ & $\begin{array}{l}\text { Mean } \\
\text { squares }\end{array}$ & F & p-value \\
\hline Model & 3 & 4207.407 & 1402.469 & 36.627 & $<\mathbf{0 . 0 0 0 1}$ \\
\hline Error & 36 & 1378.477 & 38.291 & & \\
\hline Corrected Total & 39 & 5585.884 & & & \\
\hline
\end{tabular}

\begin{tabular}{|l|l|l|l|l|l|l|}
\hline Source & Value & Standard error & $\mathrm{t}$ & $\mathrm{p}$-value & Lower bound (95\%) & $\begin{array}{l}\text { Upper bound } \\
(95 \%)\end{array}$ \\
\hline Intercept & -7.444 & 8.084 & -0.921 & 0.363 & -23.839 & 8.952 \\
\hline WSA & 2.187 & 1.197 & 1.826 & 0.076 & -0.242 & 4.615 \\
\hline Log $_{10}$ TST (y) & 4.531 & 2.114 & 2.143 & $\mathbf{0 . 0 3 9}$ & 0.243 & 8.819 \\
\hline Total N (\%) & 83.004 & 13.959 & 5.946 & $<\mathbf{0 . 0 0 0 1}$ & 54.694 & 111.313 \\
\hline
\end{tabular}


871 Table S5: Multiple Linear Regression: WSA

872

\begin{tabular}{|l|l|l|l|l|l|}
\hline $\begin{array}{l}\text { No. } \\
\text { variables }\end{array}$ & Variables & MSE & $\mathrm{R}^{2}$ & $\begin{array}{l}\text { Adjusted } \\
\mathrm{R}^{2}\end{array}$ & $\begin{array}{l}\text { Akaike's } \\
\text { AIC }\end{array}$ \\
\hline $\mathbf{1}$ & $\log _{\mathbf{1 0}}$ TST (y) & $\mathbf{0 . 7 3 1}$ & $\mathbf{0 . 5 1 3}$ & $\mathbf{0 . 5 0 0}$ & $\mathbf{- 1 0 . 5 7 8}$ \\
\hline 2 & $\log _{10}$ TST (y) / Total N (\%) & 0.722 & 0.532 & 0.507 & -10.155 \\
\hline 3 & SOC $_{\text {unadj }}(\%) / \log _{10}$ TST (y) / Total N (\%) & 0.742 & 0.532 & 0.493 & -8.160 \\
\hline
\end{tabular}

873

\begin{tabular}{|l|l|l|l|l|l|}
\hline Source & DF & $\begin{array}{l}\text { Sum of } \\
\text { squares }\end{array}$ & $\begin{array}{l}\text { Mean } \\
\text { squares }\end{array}$ & F & p-value \\
\hline Model & 1 & 29.283 & 29.283 & 40.052 & $<\mathbf{0 . 0 0 0 1}$ \\
\hline Error & 38 & 27.783 & 0.731 & & \\
\hline Corrected Total & 39 & 57.067 & & & \\
\hline
\end{tabular}

874

875 Model parameters (WSA):

\begin{tabular}{|l|l|l|l|l|l|l|}
\hline Source & Value & Standard error & $\mathrm{t}$ & $\mathrm{p}$-value & Lower bound (95\%) & Upper bound (95\%) \\
\hline Intercept & 5.575 & 0.222 & 25.122 & $<\mathbf{0 . 0 0 0 1}$ & 5.126 & 6.024 \\
\hline SOC $_{\text {unadj }}(\%)$ & 0.000 & 0.000 & & & & \\
\hline Log $_{10}$ TST (y) & 1.262 & 0.199 & 6.329 & $<\mathbf{0 . 0 0 0 1}$ & 0.858 & \\
\hline Total N (\%) & 0.000 & 0.000 & & & & \\
\hline
\end{tabular}

876 
878 Table S6: Mean ( \pm 1 s.d.) values of soil properties ( $\mathrm{pH}$, bulk density, BD; soil organic

879 matter, \%SOM, WSA) and management type and time since tillage (TST) for each field in

880 the South Cotswolds from Smale et al., 2017.

881

\begin{tabular}{|l|l|l|l|l|l|}
\hline Farm & Management type & TST $(\mathrm{y})$ & $\begin{array}{l}\text { BD } \\
\left(\mathrm{g} \mathrm{cm}^{3}\right)\end{array}$ & $\begin{array}{l}\text { SOM } \\
(\%)\end{array}$ & $\begin{array}{l}\text { WSA } \\
\text { (score) }\end{array}$ \\
\hline 1 & Ley-Arable rotation (pigs) & 5 & $0.96(0.347)$ & $10.08(0.132)$ & 7 \\
\hline 1 & Arable & 6 & $1.41(0.082)$ & $6.00(0.160)$ & 7 \\
\hline 1 & Woodland & 70 & $1.16(0.038)$ & $9.31(0.847)$ & 8 \\
\hline 2 & Ley-arable rotation & 1 & $1.10(0.053)$ & $8.11(0.136)$ & 5 \\
\hline 2 & Permanent pasture (sheep) & 30 & $1.00(0.163)$ & $9.06(1.8)$ & 8 \\
\hline 2 & Woodland & $100+$ & $1.08(0.155)$ & $7.95(2.217)$ & 6 \\
\hline 3 & Arable & 1 & $1.34(0.094)$ & $6.18(0.179)$ & 6 \\
\hline 3 & Arable & 1 & $1.34(0.040)$ & $6.29(0.090)$ & 4 \\
\hline 4 & Ley-arable rotation & 3 & $1.07(0.230)$ & $8.49(0.225)$ & 6 \\
\hline 4 & Ley-arable rotation & 7 & $1.17(0.106)$ & $9.81(0.356)$ & 7 \\
\hline 4 & Permanent pasture (cattle/horses) & $100+$ & $0.95(0.71)$ & $14.03(1.112)$ & 7 \\
\hline 4 & Woodland & $100+$ & $0.86(0.080)$ & $13.34(0.638)$ & 7 \\
\hline 5 & Arable & 4 & $1.04(0.061)$ & $10.62(0.124)$ & 6 \\
\hline 5 & Ley-arable rotation & 7 & $0.96(0.033)$ & $11.37(0.328)$ & 4 \\
\hline 6 & Permanent pasture & 40 & $0.83(0.023)$ & $15.26(0.273)$ & 8 \\
\hline 7 & Permanent pasture (sheep/cattle) & 30 & $1.10(0.018)$ & $9.13(0.504)$ & 8 \\
\hline 7 & Woodland & $100+$ & $0.80(0.088)$ & $12.49(2.127)$ & 7 \\
\hline 7 & Ley-arable rotation (sheep/cattle) $)$ & 3 & $1.04(0.055)$ & $8.38(0.424)$ & 6 \\
\hline 7 & Ley-arable rotation & 1 & $1.07(0.058)$ & $8.52(0.222)$ & 5 \\
\hline 8 & Arable & 1 & $1.15(0.053)$ & $9.75(0.093)$ & 5 \\
\hline 8 & Ley-arable rotation & 1 & $1.00(0.123)$ & $10.44(0.370)$ & 7 \\
\hline 8 & Permanent pasture & 10 & $1.22(0.056)$ & $9.87(0.336)$ & 7 \\
\hline 8 & Permanent pasture & $100+$ & $0.87(0.050)$ & $14.47(0.809)$ & 8 \\
\hline
\end{tabular}


883 Figure S1: Map showing location of the 15 sample sites on farms in southwest England.

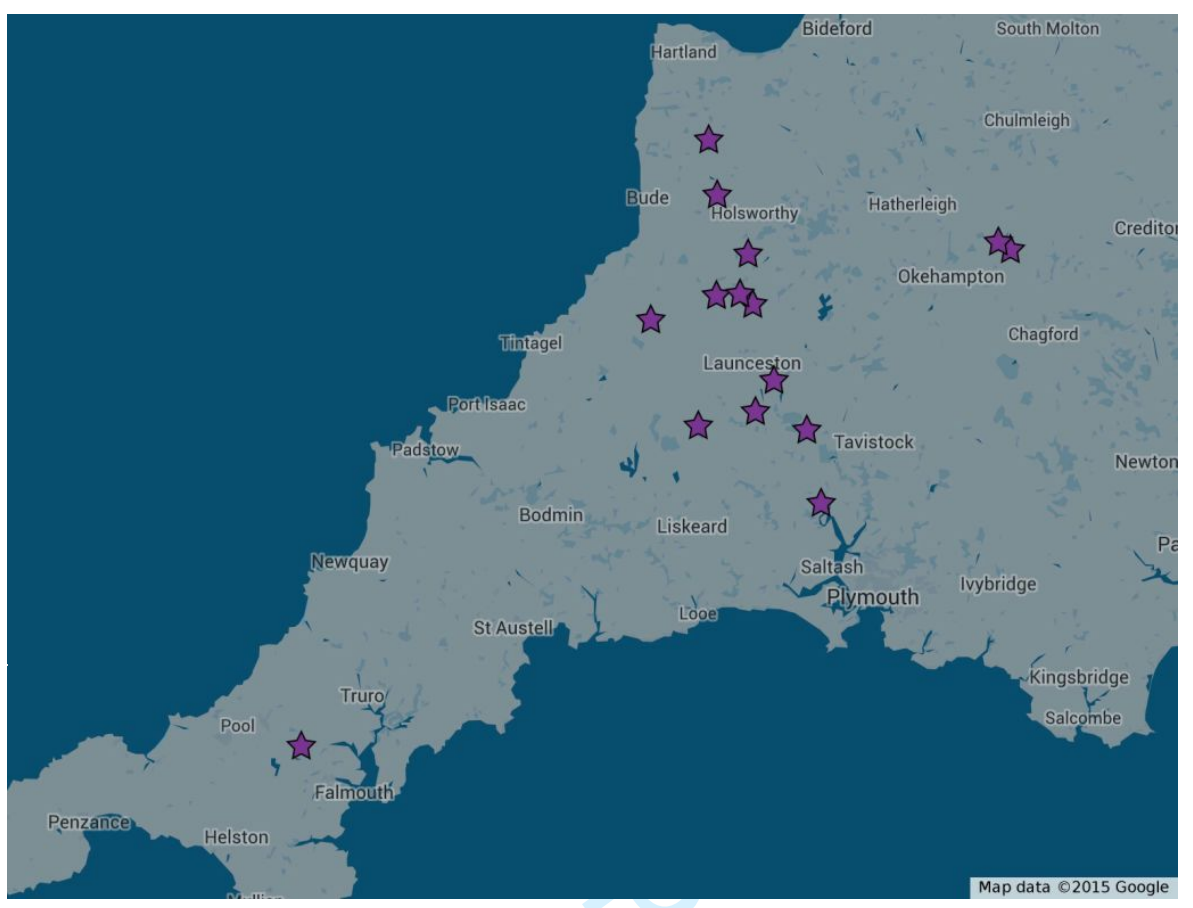

